Metals and Ceramics Division

\title{
WASTE MINIMIZATION/POLLUTION PREVENTION STUDY OF HIGH-PRIORITY WASTE STREAMS
}

R. B. Ogle, Compiler

Date Published: March 1994

NOTICE: This document contains information of a preliminary nature. It is subject to revision or correction and therefore does not represent a final report.

Prepared by the

OAK RIDGE NATIONAL LABOATORY

Oak Ridge, Tennessee 37831-6285

managed by

MARTIN MARIETTA ENERGY SYSTEMS, INC.

for the

U.S. DEPARTMENT OF ENERGY

under contract DE-AC05-84OR21400 


$$
\text { n. }
$$




\section{DISCLAIMER}

This report was .prepared as an account of work sponsored by an agency of the United States Government. Neither the United States Government nor any agency thereof, nor any of their employees, make any warranty, express or implied, or assumes any legal liability or responsibility for the accuracy, completeness, or usefulness of any information, apparatus, product, or process disclosed, or represents that its use would not infringe privately owned rights. Reference herein to any specific commercial product, process, or service by trade name, trademark, manufacturer, or otherwise does not necessarily constitute or imply its endorsement, recommendation, or favoring by the United States Government or any agency thereof. The views and opinions of authors expressed herein do not necessarily state or reflect those of the United States Government or any agency thereof. 


\section{DISCLAIMER}

Portions of this document may be illegible in electronic image products. Images are produced from the best available original document. 


\section{TABLE OF CONTENTS}

LIST OF TABLES $\ldots \ldots \ldots \ldots \ldots \ldots \ldots \ldots \ldots \ldots \ldots \ldots \ldots \ldots \ldots \ldots$

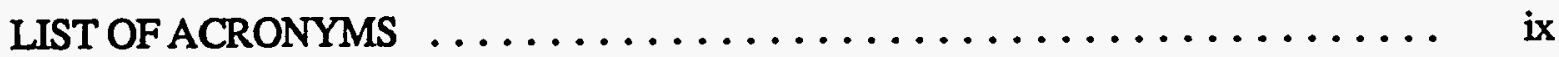

EXECUTIVE SUMMARY $\ldots \ldots \ldots \ldots \ldots \ldots \ldots \ldots \ldots \ldots \ldots \ldots \ldots \ldots \ldots$ xi

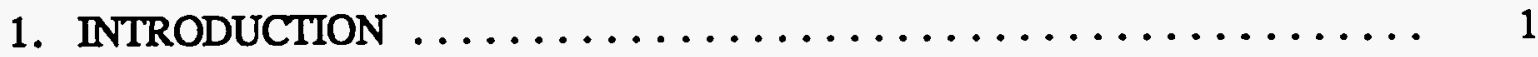

1.1 OBJECTIVES AND METHODOLOGY OF WASTE
MINIMIZATION STUDY $\ldots \ldots \ldots \ldots \ldots \ldots \ldots \ldots \ldots \ldots \ldots \ldots \ldots$

1.2 TIME FRAME AND RESOURCES FOR STUDY $\ldots \ldots \ldots \ldots \ldots \ldots 4$

1.3 SOURCES OF INFORMATION $\ldots \ldots \ldots \ldots \ldots \ldots \ldots \ldots \ldots, 4$

2. WASTE OILS WASTE MINIMIZATION TEAM ACTIVITIES $\ldots \ldots \ldots \ldots .5$

2.1 DESCRIPTION OFLABORATORY OPERATIONS GENERATING WASTE OILS $\ldots \ldots \ldots \ldots \ldots \ldots \ldots \ldots \ldots, 5$

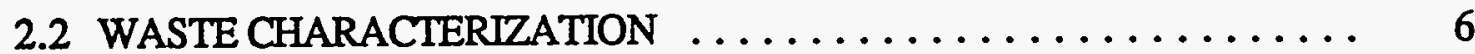

2.3 POTENTIAL WASTE MINIMIZATION/REDUCTION OPTIONS IDENTIFIED AND SCREENED $\ldots \ldots \ldots \ldots \ldots \ldots \ldots .6$

2.4 POLLUTION PREVENTION AND WASTE MINIMIZATION/ REDUCTION OPTIONS EVALUATED ................ 11

2.5 POLLUTION PREVENTION AND WASTE MINIMIZATION/ REDUCTION OPTION(S) RECOMMENDED $\ldots \ldots \ldots \ldots \ldots \ldots, 12$

3. WASTE ACIDS WASTE MINIMIZATION TEAM ACTIVITIES ........ 15

3.1 DESCRIPTION OF LABORATORY OPERATIONS GENERATING WASTE ACIDS $\ldots \ldots \ldots \ldots \ldots \ldots \ldots \ldots \ldots$

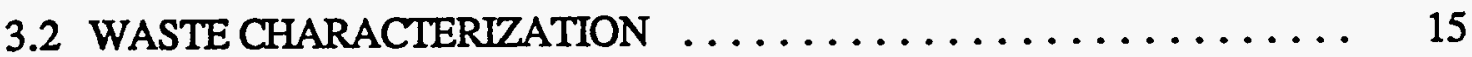

3.3 POTENTIAL WASTE MINIMIZATION/REDUCTION OPTIONS IDENTIFIED AND SCREENED $\ldots \ldots \ldots \ldots \ldots \ldots \ldots, 16$

3.4 POLLUTION PREVENTION AND WASTE MINIMIZATION/ REDUCTION OPTIONS EVALUATED ................ 19

3.5 POLLUTION PREVENTION AND WASTE MINIMIZATION/ REDUCTION OPTION(S) RECOMMENDED ............ 19

4. WASTE BUILDING EXHAUST FILTERS WASTE MINIMIZATION

TEAM ACTTVITIES $\ldots \ldots \ldots \ldots \ldots \ldots \ldots \ldots \ldots \ldots \ldots \ldots \ldots \ldots$

4.1 DESCRIPTION OF LABORATORY OPERATIONS CONTRIBUTING TO THE GENERATION OF

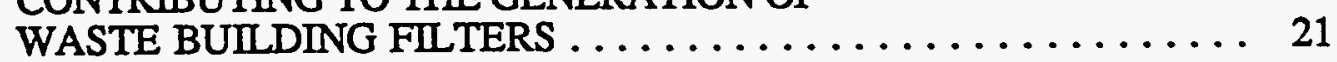

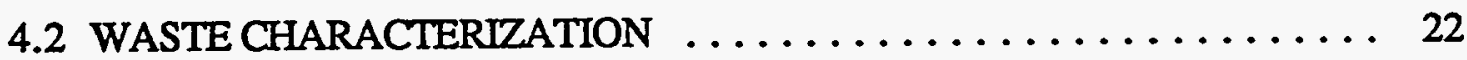

4.3 POTENTIAL WASTE MINIMIZATION/REDUCTION AND ENERGY CONSERVATION OPTIONS IDENTIFIED AND SCREENED 
4.4 WASTE MINIMIZATION/REDUCTION AND ENERGY

CONSERVATION OPTION(S) EVALUATED ............ 24

4.5 WASTE MINIMIZATION/REDUCTION AND ENERGY CONSERVATION OPTION(S) RECOMMENDED ........... 24

5. HCRH WASTE MINIMIZATION TEAM ACTIVITIES $\ldots \ldots \ldots \ldots \ldots \ldots 27$

5.1 DESCRIPTION OF LABORATORY OPERATIONS USING CHEMICALS DEEMED REPRODUCTIVE

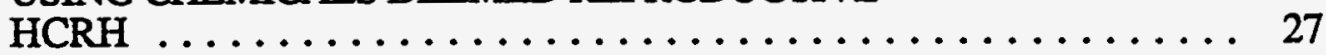

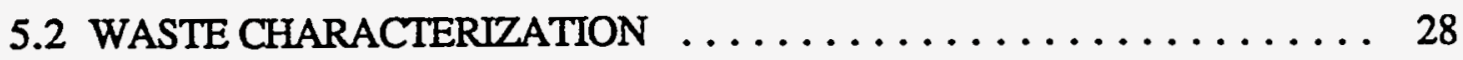

5.3 POTENTIAL WASTE MINIMIZATION/REDUCTION

OPTIONS IDENTIFIED AND SCREENED $\ldots \ldots \ldots \ldots \ldots \ldots \ldots, 28$

5.4 POLLUTION PREVENTION AND WASTE MINIMIZATION/

REDUCTION OPTIONS EVALUATED . . . . . . . . . . . . . 29

5.5 POLLUTION PREVENTION AND WASTE MINIMIZATION/

REDUCTION OPTIONS RECOMMENDED . . . . . . . . . . . 29

6. OFFICE AND MISCELLANEOUS WASTE MINIMIZATION

TEAM ACTIVITIES $\ldots \ldots \ldots \ldots \ldots \ldots \ldots \ldots \ldots \ldots \ldots \ldots \ldots$

6.1 DESCRIPTION OF OFFICE AND LABORATORY OPERATIONS

GENERATING OFFICE AND MISCELLANEOUS

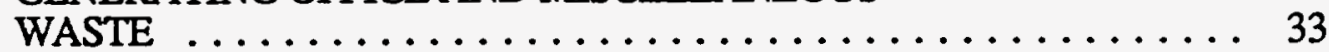

6.2 WASTE CHARACTERIZATION $\ldots \ldots \ldots \ldots \ldots \ldots \ldots \ldots \ldots, 34$

6.3 POTENTIAL WASTE MINIMIZATION/REDUCTION

OPTIONS IDENTIFIED AND SCREENED $\ldots \ldots \ldots \ldots \ldots \ldots \ldots .34$

6.4 POLLUTION PREVENTION AND WASTE MINIMIZATION/

REDUCTION OPTIONS EVALUATED ............... 34

6.5 POLLUTTON PREVENTION AND WASTE MINIMIZATION/

REDUCTION OPTION(S) RECOMMENDED $\ldots \ldots \ldots \ldots \ldots \ldots .34$

7. PHOTOGRAPHIC WASTE MINIMIZATION TEAM

ACTIVITIES . . ........................ 37

7.1 DESCRIPTION OF LABORATORY OPERATIONS GENERATING PHOTOGRAPHIC WASTE $\ldots \ldots \ldots \ldots \ldots \ldots .37$

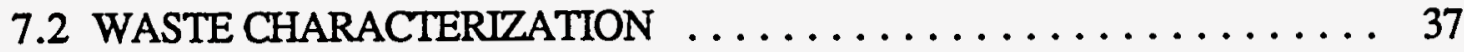

7.3 POTENTIAL WASTE MINIMIZATION/REDUCTION

OPTIONS IDENTIFIED AND SCREENED $\ldots \ldots \ldots \ldots \ldots \ldots \ldots .38$

7.4 POLLUTION PREVENTION AND WASTE MINIMIZATION

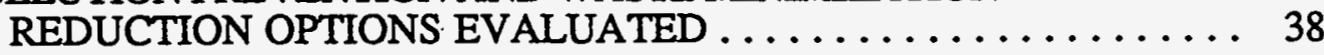

7.5 POLLUTION PREVENTION AND WASTE MINIMIZATION/

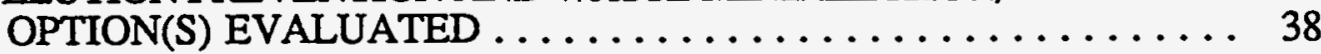

8. SUMMARY OF RECOMMENDED OPTIONS $\ldots \ldots \ldots \ldots \ldots \ldots \ldots \ldots 43$

9. ACKNOWLEDGMENTS $\ldots \ldots \ldots \ldots \ldots \ldots \ldots \ldots \ldots \ldots \ldots$

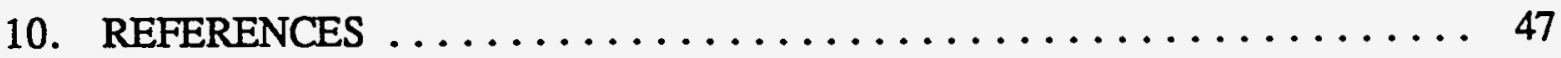


APPENDIX A - MARTIN MARIETTA ENERGY SYSTEMS, INC.

(MMES) TENTATIVE PRIMARY REPRODUCTIVE TOXINS

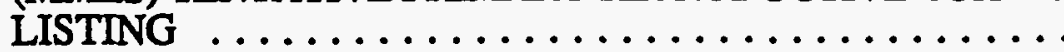

APPENDIX B - HUMAN AND SUSPECT HUMAN CARCINOGENS -

OSHA AND ACGIH $\ldots \ldots \ldots \ldots \ldots \ldots \ldots \ldots \ldots \ldots \ldots \ldots \ldots$ 


\section{LIST OF TABLES}

Table

1 Oak Ridge National Laboratory Metals and Ceramics Division Pollution Prevention Program Waste Minimization

Team Members

2 Potential waste minimization and reduction options

for Metals and Ceramics Division waste oils and oily solids

Potential waste minimization and reduction options

for Metals and Ceramics Division waste acids

$4 \quad$ Historical Data of the exhaust filter change out of

Building 4508

$5 \quad$ Potential waste minimization and reduction options

for Metals and Ceramics Division waste exhaust filters

6 Potential waste minimization and reduction options for Metals and Ceramics Division human

carcinogens and reproductive hazards

$7 \quad$ Potential waste minimization and reduction options for Metals and Ceramics Division office and miscellaneous wastes

8 Potential waste minimization and reduction options for Metals and Ceramics Division photographic 


\section{LIST OF ACRONYMS}

$\begin{array}{ll}\text { ACGIH } & \text { American Conference of Governmental Industrial Hygienists } \\ \text { AVID } & \text { Accelerated Vendor Inventory Delivery (System) } \\ \text { CAA } & \text { Clean Air Act } \\ \text { CWA } & \text { Clean Water Act } \\ \text { CY } & \text { calendar year } \\ \text { DOE } & \text { U.S. Department of Energy } \\ \text { Energy Systems } & \text { Martin Marietta Energy Systems, Inc. } \\ \text { EPA } & \text { U.S. Environmental Protection Agency } \\ \text { ES\&H } & \text { environment, safety, and health } \\ \text { FY } & \text { fiscal year } \\ \text { HAZWRAP } & \text { Hazardous Waste Remedial Actions Program } \\ \text { HCRH } & \text { human carcinogens and reproductive hazards } \\ \text { HEPA } & \text { high-efficiency particulate air } \\ \text { HMIS } & \text { Hazardous Materials Inventory System } \\ \text { HTML } & \text { High Temperature Materials Laboratory } \\ \text { HVAC } & \text { heating, ventilation, and air conditioning } \\ \text { TT } & \text { IT Corporation } \\ \text { M\&C } & \text { Metals and Ceramics Division } \\ \text { NASA } & \text { National Aeronautics and Space Administration } \\ \text { NEPA } & \text { National Environmental Policy Act } \\ \text { NPDES } & \text { National Pollutant Discharge Elimination System } \\ \text { ORNL } & \text { Oak Ridge National Laboratory } \\ \text { OSHA } & \text { Occupational Safety and Health Administration } \\ \text { P\&E } & \text { Plant and Equipment Division } \\ \text { PCB } & \text { polychlorinated biphenyl } \\ \text { ppm } & \text { parts per million } \\ \text { PWA } & \text { process waste assessment } \\ \text { RAD } & \text { radioactive } \\ \text { R\&D } & \text { research and development } \\ \text { RCRA } & \text { Resource Conservation and Recovery Act } \\ \text { RTG } & \text { Radioisotope Thermal Generator } \\ \text { SEG } & \text { Scientific Ecology Group, Inc. } \\ \text { SLLW } & \text { solid low-level waste } \\ \text { TSCA } & \text { Toxic Substance Control Act } \\ \text { WMRAD } & \text { Waste Management and Remedial Action Division } \\ & \end{array}$





\section{EXECUTIVE SUMMARY}

Although waste minimization has been practiced by the Metals and Ceramics (M\&C) Division in the past, the effort has not been uniform or formalized. To establish the groundwork for continuous improvement, the Division Director initiated a more formalized waste minimization and pollution prevention program. The vision for this program is:

Pollution prevention, as it relates to our efficient use of resources, is necessary to accomplish our long-term mission. As we progress, it must become a natural part of the cognitive process for our research and support staff. Concepts/goals such as zero waste discharge must (eventually) be seen as realistic challenges to our creative abilities.

Through the vision statement, the director recognizes the connection between the health of the division and the wise use of our resources.

Formalization of the division's pollution prevention efforts in fiscal year (FY) 1993 was initiated by a more concerted effort to determine the status of waste generation from division activities. The goal for this effort was to reduce or minimize the wastes identified as having the greatest impact on human health, the environment, and costs. Two broad categories of division wastes were identified as solid/liquid wastes and those relating to energy use (primarily electricity and steam). This report presents information on the nonradioactive solid and liquid wastes generated by division activities. More specifically, the information presented was generated by teams of M\&C staff members empowered by the Division Director to study specific waste streams.

This project began when division environment, safety, and health (ESH) personnel were tasked with the identification and quantification of division waste streams. Additionally, the ESH Group was assigned the job of determining the costs associated with waste generation in order for division leadership to make informed fiscal decisions. The group found that the more highly regulated wastes have been quantified to the division level at Oak Ridge National Laboratory (ORNL). Generally, the cost figures available to a division are limited to those associated with initial handling/transport to storage areas and some of the sampling and analysis. There were no itemized costs associated with disposal of nonhazardous solid industrial wastes (e.g., uncontaminated paper, glass, and metals) and liquid wastes discharged through the process waste drains/system. Accurate quantification of industrial waste at the division level was not feasible. (The division brought this issue to the attention of the ORNL Fix-It Committee and to the ORNL Executive Committee.) 
While it was recognized that baseline quantification and cost data were important for good management of division waste streams, the Division Director made the decision to focus further division resources on waste minimization. This was to be accomplished by empowering division staff teams (with the support of other ORNL organizations) to study M\&C's six most significant waste streams. The importance of a particular waste was determined by both objective (e.g., quantity and cost) and subjective (e.g., those posing special risks, or highly visible) considerations.

The division focused on the four largest hazardous waste streams: used oils, photographic wastes, used acids, and other miscellaneous hazardous wastes (with special focus on the subcategory, chemical reproductive toxins and carcinogens). Additionally, two other teams were tasked with studying waste building exhaust filters and office/miscellaneous nonhazardous wastes; these wastes were not readily quantifiable but were deemed important to the division.

Empowered teams were given a 10-week period to become versed on the basic tenets of waste minimization, to identify internal sources of the subject waste, to determine costs/quantities, and to make waste minimization recommendations. The teams were to consider the following alternatives, given in order of preference, in making their recommendations:

1. source reduction (such as reduction of chemical usage by process changes or substitution of toxic chemicals with less hazardous materials),

2. reuse (within the process),

3. recycle (to other users),

4. treatment (reduce the hazard), and

5. disposal

While detailed information on the empowered team studies is the subject of this report, the following is provided as a summary of team findings.

\section{WASTE OILS}

The major waste for the division has been used oils from vacuum pumps and hydraulic systems. In spite of division efforts to consolidate and control this waste stream, used oils and oily solids accounted for over $10,000 \mathrm{lb}$ of the division waste in FY 1992 with a handling cost of approximately $\$ 23,000$ (these dollar figures are given as estimated costs on reports to the division from the waste handling organization). The division incurs direct costs of required sampling/analysis of the used oil. 
The study team has identified several potential ways to reduce costs associated with the used oils and identified some promising methods of reducing the volume of used oil that was generated. Examples of possible solutions included in-place cleaning and recycling of hydraulic and vacuum pump oil, use of oilless vacuum pumps, and the utilization of used oil by the ORNL garage as a fuel for space heaters. These and other alternatives were discussed in detail in Sect. 2 of this report.

It is a recommendation that the waste oils team continue to meet during piloting of potential options so that more detailed recommendations can be finalized.

\section{WASTE ACIDS}

For calendar year (CY) 1992, about $90 \%$ of the waste acids in the division came from one project associated with iridium work. The team focused their study on that specific waste stream. The information provided to the division indicates waste acids handling costs in 1992 for the iridium work were approximately $\$ 3000$. Since there are customer/quality constraints associated with the process, source reduction and reuse alternatives are not practical. It is projected that program/project workload reductions would result in waste generation reductions of about 75\% by FY 1995.

The team determined that the optimum interim solution for waste acids is to seek approval for waste neutralization and disposal through the process waste system. This method of dealing with waste acids should eliminate external handling costs. The team suggested that the division ESH Group should follow through with obtaining approvals for the alternative waste minimization method and should work with the generator in initiation of the neutralization process. The ESH Group should also determine the feasibility for applying similar techniques to the remaining waste acid streams.

\section{BUILDING EXHAUST FILTERS}

In recent years, the accumulation of a significant volume of waste building exhaust filters has become a noticeable problem. The total cost for disposal of these filters is unknown and may be significant depending on the imposed sampling and analysis; evaluation of costs and requirements has been initiated. The team study is focused on Building 4508, since it is the source of most of the waste building exhaust filters. In reviewing the rate of generation of exhaust filters, it has been determined that the Plant and Equipment (P\&E) Division has been successful in minimizing filter changeout frequency. Although simple annual disposal costs 
(handling costs only) have reduced from approximately $\$ 5000$ to $\$ 3000$ since 1990 , we have estimated total costs for disposal at $\$ 67,500$.

It has been determined that the purpose of the 4508 facility has changed in recent years, and these changes could mean that exhaust filtration, to the current extent, may no longer be warranted. The team noted that further study of the regulatory basis for filters on the exhaust systems is recommended, and the issue should be pursued by the division ESH Group.

The team pointed out that success in reducing the number and types of filters would not only result in some savings in waste disposal costs but could yield greater savings in building energy consumption. Information should be provided to the group studying energy conservation.

\section{PHOTOGRAPHIC WASTE}

Photographic waste is the second largest Resource Conservation and Recovery Act (RCRA) waste stream generated by the division at approximately $7500 \mathrm{lb}$ in CY 1992. Although there have been several sources of photographic wastes, the division's Technical Photography Group accounted for about $90 \%$ of the waste. The handling costs for the waste have been estimated to be $\$ 4000$ per year. The team found that photographic waste could be eliminated by changing to digital processing. In fact, at least one group within the division has begun digital image processing. Initial equipment costs to convert Technical Photography to digital processing are estimated by the team to be $\$ 30,000$ to $\$ 100,000$. The team recognized other potential benefits from conversion to digital processing such as improved archival capability. Because the initial investment in this control alternative is seen as significant, the team recommends the establishment of a division committee (primarily composed of representatives from all groups that generate photographic wastes) to study and make recommendations to the Division Director on the pursuit of increased use of digital processing.

As an interim measure for reducing the RCRA hazardous waste, the team recommends the use of the ORNL-sponsored silver recovery initiative that was still being evaluated at the time the team completed its mission. The division ESH Group should continue to facilitate the silver recovery effort. Additionally, the ESH Group should evaluate individual photographic waste streams to determine if expeditious disposal means are being employed. 


\section{HUMAN CARCINOGENS AND REPRODUCTIVE HAZARDS (HCRH)}

The HCRH Team pursued the study of these categories of materials in concert with the division's industrial hygiene self-assessment on the same groups of chemicals. The study is led by a certified industrial hygienist and is focused on materials that present a significant potential for occupational exposure.

In general, it has been determined that the division followed good laboratory practices when using these special hazards. It is noted that the potential exists for further reductions in the number and amounts of HCRH in the division. It is suggested that the ESH Group pursue the initiative of improving the division's knowledge of feasible, less hazardous substitutes, and more time should be spent reviewing processes with a focus on waste minimization. The current AVID (Accelerated Vendor Inventory Delivery) system is viewed as an impediment to waste minimization because it seemed to promote purchasing larger quantities than are needed. The HMIS (Hazardous Materials Inventory System) is also deemed to be ineffective as an aid in accounting for material inventories. The division should voice these concerns and issues to management. [Note: The Division Director brought these issues to the ORNL Fix-It Committee on August 23, 1993.]

\section{OFFICE AND MISCELLANEOUS NONHAZARDOUS WASTES}

The team chartered to study this issue found that amounts and costs of these types of wastes are not tracked in a way that allows quantification at the division level. The primary team activities are aimed at gathering information on recycling opportunities potentially available to the division and included benchmarking efforts at some area organizations. In general, it is indicated that further attention should be given to utilizing programs for recycle such as the Adopt-A-School Program, aluminum can recycling, white paper recycle, and toner cartridge recycle. Many areas for additional recycling efforts exist and should be explored either at the division or ORNL level. Examples of other materials that may be recycled include wooden pallets and other types of paper. [Note: ORNL's Waste Minimization Coordinator has tentatively approved using the M\&C Division as a pilot area for recycling of miscellaneous paper waste for a proposed Aqua-Seeding project.] The general recommendation is for a division waste minimization team to be established to continue to study and make recommendations related to nonhazardous wastes. The team develop data on the current level of division participation in available recycling programs. The team should investigate barriers to participation. Finally, the team should focus on methods for reducing wastes (e.g., ways to reduce the use of all types of paper) and help establish goals for the division. 
In summary, the use of empowered teams for studying waste minimization in the division is viewed positively by the teams. With few exceptions, the team members were challenged by the task and found the exercise to be of value. The knowledge base of the division has improved through this endeavor. Detailed team recommendations and action plans are presented in the following report. 


\title{
WASTE MINIMIZATION/POLLUTION PREVENTION STUDY OF HIGH-PRIORITY WASTE STREAMS*
}

\author{
R. B. Ogle
}

\section{INTRODUCTION}

The Metals and Ceramics (M\&C) Division pollution prevention vision is as follows:

Pollution prevention, as it relates to our efficient use of resources, is necessary to accomplish our long-term mission. As we progress, it must become a natural part of the cognitive process for our research and support staff. Concepts/goals such as zero waste discharge must (eventually) be seen as realistic challenges to our creative abilities.

In support of this vision, the Division Director chartered teams to perform targeted waste minimization studies.

\subsection{OBJECTIVES AND METHODOLOGY OF WASTE MINIMIZATION STUDY}

The M\&C Pollution Prevention Program evaluated the hazardous waste, use of building exhaust filters, and the office waste generated in the division and identified the six top-priority waste streams based on toxicity and volume generated in calendar year (CY) 1992. The program then established six empowered teams to evaluate these waste streams, identify and assess possible waste minimization and reduction options, and recommend a specific option to M\&C management. While this activity is a study, several aspects of the process waste assessment (PWA) methodology described in the U.S. Department of Energy (DOE) Model Process Waste Assessment Plan ${ }^{1}$ are used by the empowered teams.

The following steps are part of the comprehensive study to identify, evaluate, and minimize these high-priority waste streams:

- identify significant waste streams,

- empower teams to perform the study and recommend options,

- adopt practical control recommendations,

- evaluate the waste minimization effort, and

- repeat the previous four steps as appropriate.

This report documents the first three steps. Once recommended waste minimization efforts have been implemented and have had at least a 6-month history of operation, the divisional waste minimization effort will be evaluated, and the first three steps will be repeated as appropriate.

*Managed by Martin Marietta Energy Systems, Inc., under contract DE-AC05-84OR21400 with the U.S. Department of Energy. 
The high-priority waste streams examined by the teams are as follows:

- waste oils,

- waste acids,

- building exhaust filters,

- human carcinogens and reproductive hazards (HCRH),

- office and miscellaneous wastes, and

- photographic wastes.

Each M\&C Waste Minimization Team had a team facilitator from the Environment, Safety, and Health (ESH) Group, a team leader selected by the team, and team members. Technical support from other Oak Ridge National Laboratory (ORNL) organizations, subcontractors, and vendors is used by each of the teams as appropriate. Other ORNL organizations supporting this effort include the Waste Management and Remedial Action Division (WMRAD), the Office of Environmental Compliance and Documentation, the Plant and Equipment (P\&E) Division, and the Graphics Division. Table 1 lists the members of each M\&C team.

During the data gathering phase, the teams tried to determine the origin of the waste stream being investigated. This determination is made by classifying the origin of the waste stream into the following:

- process chemistry,

- engineering design,

- how the activity is operated, and

- how the activity is maintained.

The teams also used three basic principles during their assessments.

- Waste minimization activities are not successful until the waste minimization solution matches the fundamental source of the waste.

- The generation of waste follows generalized repeating patterns.

- These repeating patterns are independent of specific operations.

For instance, whether a team studied the generation of waste oil or photographic waste, the true origin of each waste stream could be classified into one of the above four categories. Once the true origin of the waste is identified, the potential options identified and evaluated are tailored to address the true cause of the waste. The proposed activities and projects for 
Table 1. Oak Ridge National Laboratory Metals and Ceramics Division Pollution Prevention Program Waste Minimization Team Members

\begin{tabular}{|c|c|}
\hline Team name & Team members \\
\hline Waste oils & $\begin{array}{l}\text { M. C. Clark - Team Leader } \\
\text { R. L. Heestand } \\
\text { T. M. Kenney } \\
\text { D. H. Pierce } \\
\text { H. D. Upton } \\
\text { A. P. Ostergaard - WMRADa Subcontractor (IT)b } \\
\text { C. A. Maples - Facilitator }\end{array}$ \\
\hline Waste acids & $\begin{array}{l}\text { J. R. Mayotte } \\
\text { C. G. Westmoreland } \\
\text { C. A. Maples - Facilitator }\end{array}$ \\
\hline Building exhaust filters & $\begin{array}{l}\text { J. N. Parks - Team Leader } \\
\text { C. W. Benton } \\
\text { J. J. Coen } \\
\text { C. E. Dunn } \\
\text { G. E. Nelson } \\
\text { J. K. Bain - Facilitator }\end{array}$ \\
\hline $\begin{array}{l}\text { Human carcinogens and reproductive } \\
\text { hazards }\end{array}$ & $\begin{array}{l}\text { D. W. Coffey } \\
\text { D. A. Frederick } \\
\text { J. O. Kiggans } \\
\text { D. M. Kroeger } \\
\text { R. B. Ogle - Facilitator }\end{array}$ \\
\hline Office and miscellaneous wastes & $\begin{array}{l}\text { P. T. Thomton - Team Leader } \\
\text { M. K. Ferber } \\
\text { L. M. Parker } \\
\text { H. D. Robinson } \\
\text { G. M. Sims } \\
\text { D. J. Walmsley - Facilitator }\end{array}$ \\
\hline Photographic wastes & $\begin{array}{l}\text { J. W. Nave - Team Leader } \\
\text { K. F. Russell } \\
\text { W. H. Warwick } \\
\text { R. B. Ogle - Facilitator } \\
\text { L. Riester - Photo Imaging Support }\end{array}$ \\
\hline
\end{tabular}

aWMRAD - Waste Management and Remedial Action Division. bIT - IT Corporation. 
minimizing waste are evaluated by each team in information sharing sessions. Based on these discussions, the options are divided into the following categories with the highest preference being given to source reduction and the lowest to treatment and disposal:

- source reduction,

- reuse,

- recycle,

- neutralization at the point of generation,

- treatment at ORNL,

- treatment at another Oak Ridge facility,

- treatment off site at a commercial facility, and

- approved disposal.

\subsection{TIME FRAME AND RESOURCES FOR STUDY}

The majority of the work performed for this study is completed in 10 weeks, from July through September 1993. Some teams determined during their evaluations that further work is required in their area of study or that their team would need to continue supporting recommended waste minimization options until pilot testing is completed. The cost of the time required by the $M \& C$ teams to perform this study is absorbed by the M\&C Division.

\subsection{SOURCES OF INFORMATION}

The CY 1992 waste generation reports for M\&C generated by WMRAD using their hazardous waste management data base are used to determine high-priority waste streams. The teams assigned to evaluate options to minimize these waste streams then used various resources to obtain information on the waste stream, on potential waste minimization options, and on associated environmental compliance requirements. Resources deemed as appropriate by the teams included U.S. Environmental Protection Agency (EPA) guidance, 2,3 waste management documents, $4-6$ employee knowledge and interviews, vendor data, purchased materials data, air permits, and environmental/industrial hygiene $(\mathrm{IH})$ and safety regulations. 


\section{WASTE OILS WASTE MINIMIZATION TEAM ACTIVITIES}

The M\&C Program established the following mission for this team:

Oils make up a significant part of the division's hazardous waste. This team is chartered to study all aspects of the use and disposal of these materials as necessary to develop recommendations to ensure waste is minimized to the extent that is reasonable. The team must be aware of pertinent regulations to ensure that recommendations are compliant. Where possible, the team should provide quantitative cost information related to current waste generation, controls, and waste generation after implementation of the team's recommendations.

Based on this mission and guidance provided by $M \& C$ management, the Waste Oils Waste Minimization Team started evaluating the sources of this waste stream, the waste characteristics, potential options, costs associated with managing this waste, and estimated costs of various waste minimization options, and developed a recommended strategy for minimizing this waste stream. It should be noted that the team determined that the preferable terminology for the oil generated by M\&C processes is not "waste oil" but is "used oil." For the purposes of this report, the term "used oil" and "waste oil" are interchangeable.

\subsection{DESCRIPTION OF LABORATORY OPERATIONS GENERATING WASTE OILS}

The team determined that the majority of the waste oil generated in the M\&CDivision is from hydraulic systems and vacuum pumps. The used oil is usually deemed waste because it is contaminated with particulate matter and water. However, depending on the operation, the oil can be contaminated with other materials being used in the laboratory or in the equipment itself, such as polychlorinated biphenyls (PCBs) and chlorine. The system may also be operated at a relatively high temperature resulting in cracking of the oil. While the team was able to determine the two most probable types of systems generating waste oils, no detailed laboratory-specific information is available, and a division-wide survey of waste oil generators may be needed to support waste minimization activities described in the subsequent sections of this report. 


\subsection{WASTE CHARACTERIZATION}

The nonradioactive waste oils and waste oil-contaminated solids, and their associated handling costs, were categorized and quantified as follows (based on information supplied by ORNL Waste Management):

\section{Waste oil category}

Oil, uncontaminated

Oil, PCB contaminated

Oily solid, uncontaminated

Oily solid, PCB contaminated

Total

CY $1992(\mathrm{ab})$
$1,931.98$
$7,168.77$

578.75

877.09

$10,558.59$
Handling cost (\$)

$4,233.95$

$16,291.58$

841.20

1.666 .92

$23,033.65^{*}$

\footnotetext{
*Total costs for storage and disposal and indirect costs such as paperwork are significantly higher.
}

The solid wastes included various materials, including blotter paper and wipes. While radioactively contaminated waste oils were not in the original charter, the team decided to include these waste oils in the study whenever applicable and practical.

The waste oil generated in the M\&C Division is collected in a variety of containers from small bottles to 55-gal bung-top drums. All non-PCB and nonradioactively contaminated waste oils are consolidated in 55-gal drums at the central M\&C waste oil area. The oil is then sampled and analyzed to ensure that it is not a Resource Conservation and Recovery Act (RCRA) characteristic waste, PCB contaminated, or radioactively contaminated. The team estimates that sampling and analysis of each oil sample costs the division $\$ 1800 /$ drum. If the analytical results verify that this waste oil is not contaminated with these constituents of concern, the waste oil is deemed acceptable for recycle. The oil is currently picked up by the WMRAD and taken to storage. When waste can leave the ORNL site again, this oil will be sent for recycle.

\subsection{POTENTIAL WASTE MINIMIZATION/REDUCTION OPTIONS IDENTIFIED AND SCREENED}

Several potential waste minimization and reduction options were identified and screened. Each option is screened based on technical feasibility, research operations feasibility, and environmental compliance impacts. Table 2 lists these potential options and reasons for eliminating or further evaluating specific options. 
Table 2. Potential waste minimization and reduction options for Metals and Ceramics Division waste oils and oily solids

\begin{tabular}{|c|c|c|}
\hline $\begin{array}{l}\text { Potential waste } \\
\text { minimization/ } \\
\text { reduction option }\end{array}$ & $\begin{array}{l}\text { Waste } \\
\text { minimization/ } \\
\text { reduction } \\
\text { technique }\end{array}$ & Feasibility considerations \\
\hline $\begin{array}{l}\text { Usage of oil- } \\
\text { free vacuum } \\
\text { pumps }\end{array}$ & $\begin{array}{l}\text { Process } \\
\text { modification }\end{array}$ & $\begin{array}{l}\text { Standard oil-free pumps do not create a low enough } \\
\text { vacuum for most M\&C experiments using oil-based } \\
\text { systems (inches Hga versus microns). This option will not } \\
\text { be considered further but may be considered in the future if } \\
\text { the division survey is performed. } \\
\text { New and innovative oil-free vacuum pumps would be } \\
\text { effective but are extremely expensive. This study team } \\
\text { will continue to evaluate this option. }\end{array}$ \\
\hline $\begin{array}{l}\text { Waste oil- } \\
\text { generating } \\
\text { operations } \\
\text { shutdown }\end{array}$ & Not applicable & $\begin{array}{l}\text { This option is not feasible because operations generating } \\
\text { waste oil, such as hydraulic systems and vacuum pumps, } \\
\text { are vital to research being performed. This option will not } \\
\text { be considered further. }\end{array}$ \\
\hline $\begin{array}{l}\text { Usage of helium } \\
\text { for vacuum }\end{array}$ & $\begin{array}{l}\text { Material } \\
\text { substitution/pro- } \\
\text { cess modification }\end{array}$ & $\begin{array}{l}\text { Helium would be used to create a vacuum instead of a } \\
\text { vacuum pump. This is impractical for a laboratory } \\
\text { operation, which is small and is staffed a maximum of } \\
12 \mathrm{~h} / \mathrm{d} \text {. Also, a helium system would be cost prohibitive. } \\
\text { This option will not be considered further. }\end{array}$ \\
\hline $\begin{array}{l}\text { Usage of } \\
\text { contaminant } \\
\text { traps in line in } \\
\text { front of vacuum } \\
\text { pump }\end{array}$ & Segregation & $\begin{array}{l}\text { Most vacuum systems already have traps in front of them } \\
\text { including desiccant and scrubbers. A nitrogen finger trap } \\
\text { would not be practical for a laboratory operation, which is } \\
\text { small and is staffed a maximum of } 12 \mathrm{~h} / \mathrm{d} \text {. This option will } \\
\text { not be considered further but should be included if a } \\
\text { division-wide survey of waste oil generators is performed. }\end{array}$ \\
\hline $\begin{array}{l}\text { Filter system to } \\
\text { recycle oil }\end{array}$ & Recycle/reuse & $\begin{array}{l}\text { The filter systems being considered remove particulate and } \\
\text { water contamination from the waste oil. Waste oil may } \\
\text { contain other contaminants of concern such as chlorine or } \\
\text { PCBs }{ }^{b} \text { or the waste oil may be cracked. Both of these } \\
\text { potential scenarios may limit the systems where oil can be } \\
\text { recycled. Also, cross contamination of PCBs between } \\
\text { systems is a concem, which would require separate } \\
\text { systems to be procured and used in designated laboratories } \\
\text { only. This study team will continue to evaluate } \\
\text { this option. }\end{array}$ \\
\hline
\end{tabular}


Table 2. (Continued)

\begin{tabular}{|c|c|c|}
\hline $\begin{array}{l}\text { Potential waste } \\
\text { minimization/ } \\
\text { reduction option }\end{array}$ & $\begin{array}{l}\text { Waste } \\
\text { minimization/ } \\
\text { reduction } \\
\text { technique }\end{array}$ & Feasibility considerations \\
\hline Off-site recycle & Recycle/reuse & $\begin{array}{l}\text { ORNL is not allowed to send waste oil off site for recycle } \\
\text { at this time. This option will not be considered further. }\end{array}$ \\
\hline $\begin{array}{l}\text { Usage of oil in } \\
\text { space heaters }\end{array}$ & $\begin{array}{l}\text { Reuse/energy } \\
\text { recovery }\end{array}$ & $\begin{array}{l}\text { The garage is planning to employ space heaters that burn } \\
\text { used oil for energy recovery. M\&C may be able to either } \\
\text { (1) send its non-radioactively and non-PCB-contaminated } \\
\text { oil to the garage for their use or (2) buy space heaters for } \\
\text { use in heating some of M\&CCs areas. The garage should } \\
\text { be used as the ORNL pilot, and M\&C Mhould follow up on } \\
\text { this option if the garage's pilot is successful. This study } \\
\text { team will continue to evaluate this option. }\end{array}$ \\
\hline $\begin{array}{l}\text { Distillation of } \\
\text { waste oil into } \\
\text { diesel fuel }\end{array}$ & $\begin{array}{l}\text { Recyciefreuse/ } \\
\text { energy recovery }\end{array}$ & $\begin{array}{l}\text { Waste Energy, Inc., has distillation systems that transform } \\
\text { waste oil into diesel fuel that can be subsequently used. } \\
\text { This option should be considered only if burning the oil for } \\
\text { energy recovery in space heaters is not possible. This } \\
\text { study team will continue to evaluate this option } \\
\text { only if using waste oil in space heaters is } \\
\text { deemed impractical. }\end{array}$ \\
\hline $\begin{array}{l}\text { Trearment at } \\
\text { ORNL }\end{array}$ & Waste reduction & $\begin{array}{l}\text { No waste oil treatment options are available at ORNL at } \\
\text { this time. This option will not be considered further. }\end{array}$ \\
\hline $\begin{array}{l}\text { Treatment at } \\
\text { SEGc }\end{array}$ & Waste reduction & $\begin{array}{l}\text { SEG does not have an RCRAd or TSCAE (PCB) permit at } \\
\text { this time, and a contract between SEG and Energy Systems } \\
\text { is not in place to accept waste oils or oily solids. This } \\
\text { option will not be considered further. }\end{array}$ \\
\hline $\begin{array}{l}\text { Treament at } \\
\text { K-25 TSCA } \\
\text { incinerator }\end{array}$ & Reduction & $\begin{array}{l}\text { The K-25 incinerator only handles liquid wastes and } \\
\text { cannot handle drummed liquid wastes at this time because } \\
\text { container transfer operations need to be upgraded. K-25 is } \\
\text { currently evaluating whether M\&C waste oil would even } \\
\text { meet their waste acceptance criteria and if M\&C could } \\
\text { either tanker its oil to be sent to K-25 or send it to Y-12 to } \\
\text { be bulked with their oils and subsequently sent to K-25. } \\
\text { This study team will continue to evaluate this } \\
\text { option. }\end{array}$ \\
\hline Disposal & Not applicable & $\begin{array}{l}\text { No disposal options are available for this waste oil or oily } \\
\text { solids. This option will not be considered further. }\end{array}$ \\
\hline
\end{tabular}


Table 2. (Continued)

\begin{tabular}{|c|c|c|}
\hline $\begin{array}{l}\text { Potential waste } \\
\text { minimization/ } \\
\text { reduction option }\end{array}$ & $\begin{array}{l}\text { Waste } \\
\text { minimization/ } \\
\text { reduction } \\
\text { technique }\end{array}$ & Feasibility considerations \\
\hline $\begin{array}{l}\text { Blotter paper, } \\
\text { wipes, etc., } \\
\text { recycle/reuse }\end{array}$ & Recycle/reuse & $\begin{array}{l}3 \mathrm{M} \text { produces a reusable wipe that when soaked with oil is } \\
\text { either put through a wringer system or a centrifuge to } \\
\text { remove the excess oil and use the wipes again. The wipes } \\
\text { were piloted and appear to perform satisfactorily, though } \\
\text { they were not wrung out and reused because M\&C did not } \\
\text { have a wringer. However, the safety and environmental } \\
\text { compliance issues that may be associated with these wipes } \\
\text { need to be examined. Some laboratories in M\&C may be } \\
\text { able to use these wipes. This study team will } \\
\text { continue to evaluate this option. }\end{array}$ \\
\hline Tuff tanks & Reuse & $\begin{array}{l}\text { If (1) M\&C collected its oil in } 220 \text {-gal tuff tanks, ( } 2 \text { this } \\
\text { oil is transferred into a storage tank, and ( } 3 \text { ) the tuff tanks } \\
\text { were returned to M\&C, then the waste drums associated } \\
\text { with the oil would be eliminated, and analytical costs } \\
\text { would be decreased (i.e., one sample per tuff tank instead } \\
\text { of four samples for four drums). ORNLa does not have } \\
\text { waste oil storage tanks, so the tuff tanks would not } \\
\text { currently help. If they could be used in combination with } \\
\text { perhaps sending the waste oil to Y-12 and/or } \mathrm{K}-25 \text { for } \\
\text { bulking and then the tuff tanks returned, the tuff tanks } \\
\text { could be used. At this time, this option will not be } \\
\text { considered further. }\end{array}$ \\
\hline $\begin{array}{l}\text { Survey to } \\
\text { identify PCB- } \\
\text { contaminated } \\
\text { equipment }\end{array}$ & Segregation & $\begin{array}{l}\text { M\&C has performed a survey to determine what systems } \\
\text { are PCB contaminated. However, legacies of PCBs left in } \\
\text { systems do not always show up every time a system is } \\
\text { sampled. So some that may be deemed as non-PCB may } \\
\text { at times contain oil over } 2 \text { parts per million (ppm) PCB. } \\
\text { This study team will continue to evaluate this } \\
\text { option. }\end{array}$ \\
\hline PCB test kit & Segregation & $\begin{array}{l}\text { If an EPA } h \text { approved affordable test kit for PCBs could be } \\
\text { found, it could be used for (1) identifying systems } \\
\text { containing PCBs and (2) testing oil brought to the central } \\
\text { oil storage area before buiking to avoid contaminating a } \\
55 \text {-gal drum of waste oil with a 5-gal can of } \\
\text { PCB-contaminated waste oil. This study team will } \\
\text { continue to evaluate this option. }\end{array}$ \\
\hline
\end{tabular}


Table 2. (Continued)

\begin{tabular}{|l|l|l|}
\hline $\begin{array}{l}\text { Potential waste } \\
\text { minimization/ } \\
\text { reduction option }\end{array}$ & $\begin{array}{l}\text { Waste } \\
\text { minimization/ } \\
\text { reduction } \\
\text { technique }\end{array}$ & \multicolumn{1}{|c|}{ Feasibility considerations } \\
\hline $\begin{array}{l}\text { Oil quality } \\
\text { instrument/kit }\end{array}$ & Recycle/reuse & $\begin{array}{l}\text { If the on-site oil recycle system is selected as an option and } \\
\text { if the pilot is successful, an oil quality testing system is } \\
\text { needed to ensure that the recycled oil is of acceptable } \\
\text { quality. This study team will continue to evaluate } \\
\text { this option. }\end{array}$ \\
\hline $\begin{array}{l}\text { Energy systems } \\
\text { (2 ppim) } \\
\text { modification }\end{array}$ & $\begin{array}{l}\text { Procedural } \\
\text { change }\end{array}$ & $\begin{array}{l}\text { Energy Systems has set a 2 ppm limit of PCBs for } \\
\text { deeming a waste a TSCA regulated waste, while the } \\
\text { regulations use a 50 ppm limit. If this 2 ppm limit is } \\
\text { increased, M\&C would have greater flexibility in managing } \\
\text { much of the waste categorized as PCB contaminated. } \\
\text { However, it is unlikely that this limit will be changed. } \\
\text { This option will not be considered further. Division } \\
\text { management should bring this issue to ORNL } \\
\text { management's attention. }\end{array}$ \\
\hline
\end{tabular}

${ }^{a} \mathrm{Hg}=$ mercury.

$b \mathrm{PCB}=$ polychlorinated biphenyls .

c SEG = Scientific Ecology Group, Inc.

dRCRA = Resource Conservation and Recovery Act.

- TSCA = Toxic Substance Control Act.

$f \mathrm{M} \& \mathrm{C}=$ Metals and Ceramics Division.

$8 \mathrm{ORNL}=$ Oak Ridge National Laboratory.

$h \mathrm{EPA}=$ U.S. Environmental Protection Agency. 


\subsection{POLLUTION PREVENTION AND WASTE MINIMIZATION/ REDUCTION OPTIONS EVALUATED}

The potential waste oil and oily solids minimization options that were further evaluated are listed below with additional purchased equipment cost information as appropriate:

Option

Oil-free vacuum pumps

Filter system-reuse

Usage of oil in space heaters

Distillation of waste oil

Diesel fuel (only if space heater option is impractical)

Treatment at K-25 TSCA

Incinerator

Recyclable wipes

Survey to identify PCB-contaminated equipment

PCB test kit

Oil quality kit
Equipment cost

Approx. $\$ 17,000 /$ pump

$\$ 672$ to $\$ 1100$

Not applicable

Not applicable

Not applicable

$\$ 35 /$ case

Not applicable

Not applicable

$\$ 450 /$ instrument
Comments

Numerous pumps needed.

Replacement filters would be needed.

Will wait to see if garage can burn M\&C's non-PCB, nonradioactive waste oil.

Will wait to see if space heater option is viable.

No $M \& C$ equipment anticipated to be needed.

Incineration cost is about $\$ 10 / 1 b$, but incinerator budget covers this cost. Analytical cost may increase above $\$ 1800 /$ container but may be able to use larger containers.

Cost is for wipes only. Cost for centrifuge is unknown.

$\mathrm{M} \& \mathrm{C}$ has completed thorough inventories.

Still trying to find acceptable cost-effective test kit. 


\subsection{POLLUTION PREVENTION AND WASTE MINIMIZATION/ REDUCTION OPTION(S) RECOMMENDED}

Though the oil-free vacuum pumps are expensive, the team recommends continuing to evaluate them to determine the true cost of the current vacuum pumps versus the oil-free ones. For instance, if the oil-free pumps have a longer life expectancy or the true cost of waste oil management is very high, then these pumps may be practical. At this time, procuring new and innovative oil-free pumps in M\&C would not be cost effective for the division because the division is only charged for handling, and analytical costs associated with the waste oil and a vacuum pump usually contain, at most, a quart to a gallon of oil. The team recommends coordinating this effort with the Waste Minimization/Reduction Program's efforts to quantify the true costs of waste.

The team recommends that an oil-filtering unit be purchased to perform a pilot test of the system. A non-PCB, nonradioactive-contaminated oil waste stream, such as an hydraulic oil system, will be used as the testing area. A sample of the oil will be pulled before and after testing to determine how much particulate and water is removed from the oil and if the cleaned oil still meets the procurement specifications. If this filtering system does clean the oil, and if the oil meets specifications, then the team recommends purchasing either a hand-held or cart system for each laboratory area in M\&C in which the oil is mainly contaminated with particulates and water. If the oil is cleaned but does not meet specifications, then the team will investigate if additional oil processing, such as replacing spent additives, will allow the oil to be reused.

If the filtration system pilot is successful, the team also recommends procuring and piloting one oil quality instrument kit. This instrument will be tested on recycled oil, and a sample of the oil will also be sent for analysis to ascertain the instrument's ability to determine if the oil is of acceptable quality. If this instrument is reliable, it will allow the users of the filtration system to determine if the cleaned oil is of acceptable quality.

The team recommends coordinating efforts with the ORNL garage. If the garage can burn the division's non-PCB, nonradioactive waste oil in space heaters, energy recovery would be realized. The team recommends allowing the garage to completely implement their space heater project and then address whether the garage can also burn M\&C waste oil. If they cannot, the team recommends obtaining all of the pertinent information such as vendors, models, and costs of the space heaters and implementing similar heaters in M\&C areas as appropriate. If this is also impractical, as a last resort, the division should investigate systems that distill the waste oil into diesel fuel that can be used in emergency generators or heaters. 
To reduce the solid wastes generated from oil use, the team recommends procuring a pilot supply of the reusable wipes before actually considering full implementation. If enough M\&C researchers are willing to use recycled wipes, then $M \& C$ should consider obtaining a wringer system(s) or surveying excess equipment for an acceptable centrifuge(s). The health and safety considerations of these wipes must also be addressed and documented to ensure safe use.

To support waste minimization and environmental compliance, the M\&C Division has performed a survey to identify $\mathrm{PCB}$-contaminated equipment. Where applicable, the equipment will be replaced, and PCB-contaminated equipment will be offered for disposal. The team supports this effort because it will minimize PCB-contaminated waste oil and facilitate recycling of waste oil.

If an economical, EPA-approved PCB test kit can be identified, the team recommends purchasing this kit. However, at this time, the team has not identified one and recommends that team members continue to try to find such a kit. 


\section{WASTE ACIDS WASTE MINIMIZATION TEAM ACTIVITIES}

The M\&C Program established the following mission for this team:

Acids make up a significant part of the division's hazardous waste. This team is chartered to study all aspects of the use and disposal of these materials necessary to develop recommendations to ensure waste minimization to the extent that is reasonable. The team must be aware of pertinent regulations to ensure that recommendations are compliant. Where possible the team should provide quantitative/cost information related to current waste generation, controls, and waste generation after implementation of the team's recommendations.

Based on this mission and guidance provided by M\&C management, the Waste Acids Waste Minimization Team started evaluating the sources of this waste stream, the waste characteristics, potential minimization and reduction options, cost associated with managing this waste and various waste minimization options, and developing a recommended strategy for minimizing this waste stream.

\subsection{DESCRIPTION OF LABORATORY OPERATIONS GENERATING WASTE ACIDS}

The team determined that currently $88 \%$ of the waste acid generated in the M\&CDivision is from iridium work. At the time of this study, significant iridium work in the division was associated with the Radioisotope Thermal Generator (RTG) Program. These terms, "iridium work" and "RTG Program," are used interchangeably. The acid from this work is used to remove protective materials, mainly molybdenum, from the iridium after it has been rolled and formed. The acid is used until it is past the point of saturation and no longer removes the protective layer on the product. The waste acid drum often contains sludge from molybdenum and other contaminants precipitating out of the waste acid solution.

\subsection{WASTE CHARACTERIZATION}

The nonradioactive waste acids and associated handling costs were categorized and quantified as follows:

Waste acid

RTG Program acid

Other M\&C acids

Total
Quantity generated in CY $1992(\mathrm{bb})$

1352

177

1529
Handling cost (\$)

2766

784

3550 
The waste acids are collected in various sized containers from small bottles to 55-gal drums. Because the waste acid stream from the RTG Program accounts for $88 \%$ of M\&C's waste acids, this study concentrated on this specific waste stream. This waste stream is not currently analyzed prior to being offered for disposal. Waste stream characterization is based on process knowledge. Through an interview with personnel responsible for this process, this waste stream was characterized as approximately $50 \%$ nitric acid by weight and $10 \%$ molybdenum by weight (the fluid would contain a low concentration of metals, and the associated metal salts would be found primarily as precipitated solids and sludge). This waste stream may also contain lesser amounts of sulfuric acid, hydrofluoric acid, and parts per million (ppm) levels of iron and carbon. The current amount generated is about 120 gal/year. However, the work level in this area is expected to decrease. The following reductions are anticipated based on fiscal year (FY) 1992 levels:

Time frame

FY 1993

FY 1994

FY 1995
Approximate forecasted percent reduction (\%)

0

50

75

This anticipated reduction is based on decreased workload not on waste minimization efforts; therefore, if this area is required to perform additional work in the future, these reduction estimates will not be met. The team continued to evaluate potential waste minimization and reduction options.

\subsection{POTENTIAL WASTE MINIMIZATION/REDUCTION OPTIONS IDENTIFIED AND SCREENED}

Several potential waste minimization and reduction options were identified and screened. Each option was screened for technical feasibility, research operations feasibility, and environmental compliance impacts. Specific regulatory concerns that needed to be addressed were initial RCRA compliance, initial waste treatment acceptance that is associated with the process waste treatment system's capabilities, National Pollutant Discharge Elimination Systems (NPDES) permit limits under the Clean Water Act (CWA), documentation of continual waste treatment acceptance, identification and satisfaction of the National Environmental Policy Act (NEPA) requirements, and Clean Air Act (CAA) compliance. Table 3 gives these options and gives reasons for eliminating or further evaluating specific options. 


\section{Potential waste minimization and reduction options for Metals and Ceramics Division waste acids}

\begin{tabular}{|c|c|c|}
\hline $\begin{array}{l}\text { Potential waste } \\
\text { minimization/ } \\
\text { reduction option }\end{array}$ & $\begin{array}{l}\text { Waste } \\
\text { minimization/ } \\
\text { reduction } \\
\text { technique }\end{array}$ & Feasibility considerations \\
\hline $\begin{array}{l}\text { Replace acid with } \\
\text { nonhazardous } \\
\text { chemical or } \\
\text { mechanical method } \\
\text { for removing } \\
\text { molybdenum }\end{array}$ & $\begin{array}{l}\text { Material } \\
\text { substitution/ } \\
\text { process } \\
\text { modification }\end{array}$ & $\begin{array}{l}\text { Not feasible because acid is tied to NASAa } \\
\text { standards/requirements. Even if a substitute could be } \\
\text { found, by the time the paperwork was completed for } \\
\text { changing the procedure, the project generating the acid } \\
\text { waste would be practically finished. This option will } \\
\text { not be considered further. }\end{array}$ \\
\hline $\begin{array}{l}\text { Reuse/recycle } \\
\text { waste acid }\end{array}$ & Recyclefreuse & $\begin{array}{l}\text { There are other nitric acid users at ORNL } b \text {, but they } \\
\text { cannot use the acid due to the presence of contaminants } \\
\text { such as the molybdenum, total dissolved solids, and } \\
\text { total suspended solids. This option will not be } \\
\text { considered further. } \\
\text { There are some acid recycle systems that are in place, } \\
\text { including one in the enriched uranium area at Y-12, but } \\
\text { with M\&C's relatively low generation rate, a recycle } \\
\text { system is not practical, even if a user was found that } \\
\text { could use it after it was recycled. (The NASA standards } \\
\text { would not allow for the use of this recycled acid.) This } \\
\text { option will not be considered further. } \\
\text { The acid is used until it no longer removes the } \\
\text { molybdenum because it is more than saturated. (The } \\
\text { molybdenum actually precipitates out of solution in the } \\
\text { drum.) The saturated acid cannot be used further in the } \\
\text { generating process. This option will not be considered } \\
\text { further. }\end{array}$ \\
\hline $\begin{array}{l}\text { Collect different } \\
\text { types of acids in } \\
\text { separate containers }\end{array}$ & Segregation & $\begin{array}{l}\text { There is very little waste acid generated in this area that } \\
\text { does not contain nitric acid. Because this acid is } \\
\text { generated in relatively small quantities and contains high } \\
\text { levels of contaminants (i.e., solids, etc.), segregation } \\
\text { would be of ro benefit. This option will not be } \\
\text { considered further. }\end{array}$ \\
\hline
\end{tabular}


Table 3. (Continued)

\begin{tabular}{|l|l|l|}
\hline $\begin{array}{l}\text { Potential waste } \\
\text { minimization/ } \\
\text { reduction option }\end{array}$ & $\begin{array}{l}\text { Waste } \\
\text { minimization/ } \\
\text { reduction } \\
\text { technique }\end{array}$ & \multicolumn{1}{|c|}{ Feasibility considerations } \\
\hline $\begin{array}{l}\text { Process } \\
\text { neutralization and } \\
\text { discharge }\end{array}$ & Waste reduction & $\begin{array}{l}\text { A neutralization system that is sized for small laboratory } \\
\text { waste streams was investigated and found to be } \\
\text { technically feasible. The system would neutralize the } \\
\text { acid, collect the precipitated nonhazardous solids, and } \\
\text { the neutralized decant would be released to the process } \\
\text { drain in a controlled manner. This study is } \\
\text { complete. }\end{array}$ \\
\hline $\begin{array}{l}\text { Trearment and } \\
\text { discharge at ORNL }\end{array}$ & Waste reduction & $\begin{array}{l}\text { There is no specific treatment system at ORNL that can } \\
\text { handle nitric acid waste in a concentrated form. This } \\
\text { option will not be considered further. }\end{array}$ \\
\hline $\begin{array}{l}\text { Treatment and } \\
\text { discharge at Y-12 }\end{array}$ & Waste reduction & $\begin{array}{l}\text { The Y-12 West End Treatment Facility can handle nitric } \\
\text { acid waste. However, Y-12 only accepts liquids. } \\
\text { Therefore, the waste acid decant would have to be } \\
\text { transferred to another drum before being sent to Y-12. } \\
\text { This study will continue to evaluate this } \\
\text { option only if using the neutralization system } \\
\text { is deemed unacceptable. }\end{array}$ \\
\hline $\begin{array}{l}\text { Off-site treatment } \\
\text { and discharge }\end{array}$ & Waste reduction & $\begin{array}{l}\text { Off-site treatment and discharge options are not practical } \\
\text { due to the constraints involved in sending waste off site. } \\
\text { This option will not be considered further. }\end{array}$ \\
\hline
\end{tabular}

aNASA - National Aeronautics and Space Administration.

bORNL - Oak Ridge National Laboratory. 


\subsection{POLLUTION PREVENTION AND WASTE MINIMIZATION/ REDUCTION OPTIONS EVALUATED}

The potential waste acid reduction options that were further evaluated are listed below with additional purchased equipment cost information as appropriate:

Option

Neutralization system

Treatment at $\mathrm{Y}-12$
Purchased equipment cost

$\$ 9500$

Not applicable
Comments

Free on board, San Carlos, California.

Will only consider if neutralization system is not acceptable.

\subsection{POLLUTION PREVENTION AND WASTE MINIMIZATION/ REDUCTION OPTION(S) RECOMMENDED}

The team recommends batch neutralization of the waste acids with disposal to the process waste system. Batch neutralization may be performed using either a manual system/procedure or automated systems. While automated systems require a greater capital investment, they may provide greater process control and reduce manpower needs. The team recommends manual neutralization initially. If the manpower requirements become excessive, a change to an automated system could be pursued.

The team has worked with the WMRAD, the ORNL Environmental Compliance Solid and Hazardous Waste Compliance Group, and the Laboratory Certification Official for Liquid Wastes to ensure that this system will comply with all requirements. 


\section{WASTE BUILDING EXHAUST FILTERS WASTE MINIMIZATION TEAM ACTIVITIES}

The M\&C Program established the following mission for this team:

Building exhaust filters make up a significant part of the division's hazardous waste. This team is chartered to develop recommendations to ensure that hazardous waste in the form of building exhaust filters is minimized to the extent that is reasonable. The team must be aware of pertinent regulations to ensure that recommendations are compliant. Where possible the team should provide quantitative/cost information related to current waste generation, controls, and waste generation after implementation of the team's recommendations.

Based on this mission and guidance provided by M\&C management, the Waste Building Exhaust Filters Waste Minimization Team started evaluating the sources of this waste stream, the waste characteristics, potential minimization and reduction options, cost associated with managing this waste and of various waste minimization options, and developing a recommended strategy for minimizing this waste stream.

\subsection{DESCRIPTION OF LABORATORY OPERATIONS CONTRIBUTING TO THE GENERATION OF WASTE BUILDING FILTERS}

The team found that the waste building exhaust filters were generated from all of the buildings containing $M \& C$ research and development $(R \& D)$ operations. These filters were designed to remove particulate matter from the air discharges of the heating, ventilation, and air conditioning (HVAC) systems, which service the $R \& D$ areas. To facilitate this study, the team selected Building 4508 as its area of study. Changing out the filters for this building resulted in about $500 \mathrm{ft}^{3}$ of solid low-level radioactive waste (SLLW) during 1992. The ideas developed for this building could then be applied to other buildings containing M\&C R\&D operations.

Building 4508 is a two-floor building with 150 people evenly distributed between the two floors. Of these 150 people, 25 are craftsmen, 75 are technicians, 25 are administrative support, and 25 are engineers and scientists. The building supports 36 separate operations currently being conducted. Two of these operations require air permits under the CAA, and one requires the high-efficiency particulate air (HEPA) filters in the HVAC system to meet the permitting exemption requirements. The space allocation in this building is two-thirds for laboratories and shops and one-third for office areas. The energy consumption for Building 4508 totals about 40,000 million British thermal units per year (MBtu/year) with about $80 \%$ $(32,000 \mathrm{MBtu} /$ year) being used for HVAC. The resulting utility costs are about $\$ 1$ million/year 
total with about $\$ 800,000 /$ year being allocated for HVAC. The approximate HVAC energy distribution for this building is further broken down as follows:

$\begin{array}{lc}\quad \text { Use } & \text { Estimated energy consumption (MBtu/year) } \\ \text { Heating/cooling } & 18,000 \\ \text { Supply fans } & 5,000 \\ \text { Exhaust fans } & 9,000\end{array}$

The general industrial hygiene (II) air flow requirements for this building dictate that the HVAC must be a once-through system (i.e., non-recirculating system), that the system have at least 10 air turnovers $/ \mathrm{h}$, and that the system have at least $25 \mathrm{ft} 3 / \mathrm{min}$ of air flow per employee. This system complies with all of these requirements, and any alternatives must comply also.

The approximate costs for the (recent) changing filters on Building 4508 exhaust systems are estimated as follows:

1. Cost of filters

2. Removal/installation

3. DOP testing

4. RAD sampling

5. RCRA sampling

6. Package waste [solid low-level]

$[130 @ \$ 140]=$

$=$

[4 man-days]

7. Waste documentation

8. Transport to compactor

9. Burial TOTAL ESTIMATED COST

$\begin{array}{lr}= & 2,300 \\ = & 4,000 \\ = & 4,000 \\ = & 1,800 \\ = & 3,000 \\ = & 1,200 \\ = & \$ 25,000 \\ = & \$ 67,500\end{array}$

\subsection{WASTE CHARACTERIZATION}

The history of the generation of the waste building exhaust filters was reviewed with the help of the P\&E Division. Prior to 1990, the filters were changed annually regardless of their condition. Starting in 1990, the filters were changed when they became loaded with particulate matter as measured using the pressure drop across the filter. This reduced the waste stream by about $50 \%$ as shown in Table 4. 
Table 4. Historical data of the exhaust filter changeout of Building 4508

\begin{tabular}{|l|l|l|l|l|l|l|}
\hline Year & $\begin{array}{l}\text { Material cost } \\
(\$)\end{array}$ & $\begin{array}{l}\text { Labor cost } \\
(\$)\end{array}$ & $\begin{array}{l}\text { Disposal } \\
\text { cost }(\$)\end{array}$ & Total cost $(\$)$ & $\begin{array}{l}\text { Approximate } \\
\text { SLLWa generated } \\
\left(\mathrm{ft}^{3}\right)^{b}\end{array}$ & \multicolumn{1}{c|}{ Comments } \\
\hline Pre-1990 & 31,000 & 8,000 & 5,000 & 44,000 & 1,000 & $\begin{array}{l}\text { All filters changed out annually, } \\
\text { regardless of condition. }\end{array}$ \\
\hline 1990 & 20,000 & 4,000 & 3,000 & 27,000 & 500 & $\begin{array}{l}\text { Filters changed out based on loading, } \\
\text { which was determined by pressure drop } \\
\text { across a specific filter. }\end{array}$ \\
\hline 1991 & 8,000 & 3,000 & 2,000 & 13,000 & 300 & $\begin{array}{l}\text { Filters changed out based on loading, } \\
\text { which was determined by pressure drop } \\
\text { across a specific filter. }\end{array}$ \\
\hline 1992 & 17,000 & 4,000 & 3,000 & 24,000 & 500 & $\begin{array}{l}\text { Filters changed out based on loading, } \\
\text { which was determined by pressure drop } \\
\text { across a specific filter. }\end{array}$ \\
\hline
\end{tabular}

aSLLW - solid low-level waste.

$b \mathrm{ff}^{3}$ - cubic feet. 


\subsection{POTENTIAL WASTE MINIMIZATION/REDUCTION AND ENERGY CONSERVATION OPTIONS IDENTIFIED AND SCREENED}

The team identified and screened several potential waste minimization and reduction options. Each option was screened based on technical feasibility, research operations feasibility, and ESH compliance impacts. These options are listed in Table 5.

\subsection{WASTE MINIMIZATION/REDUCTION AND ENERGY CONSERVATION OPTIONS EVALUATED}

The potential waste exhaust filter minimization options that were evaluated further are listed below:

Option

Type B-2000 filters

Ductwork survey

Local HEPA filter

Variable-speed fan
Cost information

Less than $\$ 67,500 /$ year

for HEPA and

B-2000 filters
Comments

Need to perform survey before implementing.

Not applicable

Need to establish policy.

Not applicable
Scheduled for FY 1994. Combining office areas into modules with dedicated HVAC system would reduce energy usage and cost and waste generation.

\subsection{WASTE MINIMIZATION/REDUCTION AND ENERGY CONSERVATION OPTION(S) RECOMMENDED}

Based on this study, the team recommends the following activities:

- Perform a detailed environmental and health physics (HP) survey of building ductwork to provide a technical basis for determining the necessity of the current HEPA filters.

- Evaluate the results of the detailed study. The evaluation team should be comprised of requisite expertise to provide technical approval of the results, such as professionals in $\mathrm{IH}$, $\mathrm{HP}$, environmental compliance, safety compliance, and quality assurance. 


\section{Table 5. Potential waste minimization and reduction options for Metals and Ceramics Division waste exhaust filters}

\begin{tabular}{|c|c|c|}
\hline $\begin{array}{l}\text { Potential waste } \\
\text { minimization/ } \\
\text { reduction option }\end{array}$ & $\begin{array}{l}\text { Waste } \\
\text { minimization/ } \\
\text { reduction technique }\end{array}$ & Feasibility considerations \\
\hline $\begin{array}{l}\text { Waste exhaust filter- } \\
\text { generating operations } \\
\text { shutdown }\end{array}$ & Not applicable & $\begin{array}{l}\text { This option is not feasible because operations generating the exhaust } \\
\text { filters (the HVAC }{ }^{a} \text { systems) are vital for ensuring personnel safety } \\
\text { while performing research activities and a stable environment in } \\
\text { which to perform research. This option will not be considered } \\
\text { further. }\end{array}$ \\
\hline $\begin{array}{l}\text { Usage of type } \\
\text { B-2000 filters }\end{array}$ & Substitution & $\begin{array}{l}\text { If it is determined that HEPAb filters are not needed in some specific } \\
\text { HVAC systems currently using HEPA filters, then type B-2000 } \\
\text { filters could be substituted for these filters. Not only would the } \\
\text { quantity of waste generated decrease, but less energy would be needed } \\
\text { for the associated HVAC system resulting in energy conservation } \\
\text { and a reduction in the quantity of wastes generated in producing } \\
\text { electricity and steam. This study will continue to evaluate } \\
\text { this option. }\end{array}$ \\
\hline $\begin{array}{l}\text { Perform survey of } \\
\text { duct work }\end{array}$ & $\begin{array}{l}\text { Substitution/ } \\
\text { segregation }\end{array}$ & $\begin{array}{l}\text { A detailed environmental and HPc survey of building ductwork will } \\
\text { provide a technical basis for determining whether the current HEPA } \\
\text { filters are required or whether other B-2000 filters can be utilized. } \\
\text { This study will continue to evaluate this option. }\end{array}$ \\
\hline Local HEPA filters & $\begin{array}{l}\text { Process } \\
\text { modification/ } \\
\text { segregation }\end{array}$ & $\begin{array}{l}\text { HEPA filter waste could be reduced and energy conserved if a } \\
\text { Laboratory policy was implemented that required the installation of } \\
\text { local HEPA filtration as an integral part of the laboratory } \\
\text { equipment, when HEPA filters are required for the specific area. } \\
\text { This study will continue to evaluate this option. }\end{array}$ \\
\hline $\begin{array}{l}\text { Variable speed fan } \\
\text { control project }\end{array}$ & $\begin{array}{l}\text { Process } \\
\text { modification }\end{array}$ & $\begin{array}{l}\text { If the "Variable Air Velocity" Project scheduled for FY } 1994 \text { was } \\
\text { implemented, this capability was expected to provide reduced, but } \\
\text { balanced, air flow during back shifts and weekends. Filter load } \\
\text { would be somewhat reduced, but the main benefit would be reduced } \\
\text { energy usage. This study will continue to evaluate this } \\
\text { option. }\end{array}$ \\
\hline
\end{tabular}


Table 5. (Continued)

\begin{tabular}{|c|c|c|}
\hline $\begin{array}{l}\text { Potential waste } \\
\text { minimization/ } \\
\text { reduction option }\end{array}$ & $\begin{array}{l}\text { Waste } \\
\text { minimization/ } \\
\text { reduction technique }\end{array}$ & Feasibility considerations \\
\hline $\begin{array}{l}\text { Interim reduced-flow } \\
\text { configuration }\end{array}$ & $\begin{array}{l}\text { Process } \\
\text { modification }\end{array}$ & $\begin{array}{l}\text { An interim configuration of reduced flow in the off hours was } \\
\text { evaluated but would have uncertainties in establishing acceptable } \\
\text { flow balance and temperature control. This option will not be } \\
\text { considered further. }\end{array}$ \\
\hline $\begin{array}{l}\text { Engineering } \\
\text { evaluation of } \\
\text { rebalancing building } \\
\text { air flow }\end{array}$ & $\begin{array}{l}\text { Process } \\
\text { modification/ } \\
\text { segregation }\end{array}$ & $\begin{array}{l}\text { If an engineering evaluation of rebalancing the building air flow of } \\
\text { areas collected in discreet modules with dedicated HVAC was } \\
\text { performed, the energy usage and waste exhaust filter waste stream } \\
\text { would be decreased. This study will continue to evaluate } \\
\text { this option. }\end{array}$ \\
\hline
\end{tabular}

cHVAC $=$ heating, ventilation, and air conditioning.

${ }^{b} \mathrm{HEPA}=$ high-efficiency particulate air.

$c \mathrm{HP}=$ health physics.

- Replace the HEPA filters with the less expensive type B-2000 filter based on the technical approval of the results of the evaluation. This will reduce the filter change out rate since the B-2000-type filter does not load up as fast as the HEPA filter. An added benefit would be the reduced electrical power consumed due to the reduced load.

- Consider implementation of a laboratory policy that requires installation of local HEPA filtration as an integral part of the laboratory equipment when HEPA filters are required for a specific operation.

- Implement the variable-speed fan control project ("Variable Air Velocity") scheduled for FY 1994. This capability is expected to provide reduced, but balanced, air flow during back shifts and weekends. This may reduce the filter load-up rate somewhat, but the primary benefit would be the significantly reduced energy usage due to the reduced air flow rate and reduced load on heating and cooling of the air.

- Perform an engineering evaluation of rebalancing air flow with office areas collected in discreet modules with dedicated HVAC. This would reduce the volume of space designated as a laboratory area that requires the stringent $\mathrm{IH}$ requirements. Thus, this modular format would allow reduction of the air flow during normal working hours and result in lower energy costs associated with operation of fans, heaters, and chillers. 


\section{HCRH WASTE MINIMIZATION TEAM ACTIVITIES}

The M\&C Program established the following mission for this team:

While chemical reproductive toxins and carcinogens make up only a small percentage of the division's hazardous waste by volume, the potential health impact of these chemicals is significant enough to warrant minimization of their use and presence in waste. This team was chartered to study all aspects of the use and disposal of these materials and to develop recommendations to ensure waste minimization to the extent that is reasonably achievable. It was necessary for the team to identify certain specific reproductive toxins and carcinogens for waste minimization focus. The team must be aware of pertinent regulations to ensure that recommendations are compliant. Where possible the team should provide quantitative/cost information related to current waste generation, controls, and waste generation after implementation of the team's recommendations.

Based on this mission and guidance provided by M\&C management, the HCRH Waste Minimization Team started evaluating the sources for these waste streams, the waste characteristics, potential minimization and reduction options, cost associated with managing this waste and of various waste minimization options, and developing a recommended strategy for minimizing these waste streams.

\subsection{DESCRIPTION OF LABORATORY OPERATIONS USING CHEMICALS DEEMED HCRH}

The team determined that essentially all laboratory operations use some chemicals listed by regulatory agencies or Energy Systems as HCRH. The Energy Systems list of reproductive toxins is provided in Appendix A, and the DOE list of human carcinogens [from DOE Order 5480.10, Occupational Safety and Health Administration (OSHA) and American Conference of Government Industrial Hygienists (ACGIH) carcinogens] is given in Appendix B. There was widespread general laboratory use of minor HCRH solvents such as acetone, ethyl alcohol, and methyl alcohol. Use of more potent HCRH materials, nitric and hydrofluoric acids (metal surface preparation), ethylene glycol monoethyl ether, carbon tetrachloride, benzene, arsenic, photographic chemicals (formaldehyde), and lead (as counterweights and shielding) was found in limited areas of the division. 


\subsection{WASTE CHARACTERIZATION}

There was no attempt made to quantify individual waste streams for HCRH chemicals/materials. It is believed that these materials make up a significant percentage of the division's hazardous waste stream referred to as "other" wastes (to distinguish it from the more specific streams: oils/fluids, acids, and photographic wastes). The other waste stream totaled approximately $5000 \mathrm{lb}$ of waste for the division for 1992, and some portion of the total originated from each of the division's laboratory spaces.

Use and application of these chemicals in the division is varied. As is the case with general laboratory solvents, these chemicals are used in the cleaning and preparation of laboratory equipment, cleaning and surface preparation of specimens, and as basic components in laboratory chemical mixtures. The M\&C Division, as the name indicates, performs a wide variety of R\&D work (e.g., joining/welding, creep testing, and metallography) on metals that fall into the HCRH categories, such as stainless steel alloys, nickel, and chromium.

During 1993, some efforts were made to prevent pollution from R\&D activities, but these actions were not well documented. An example of a successful prevention of hazardous waste generation resulted when a low-hazard metal (based on current health information) bismuth, was substituted in an R\&D investigation by $T$. J. Huxford, rather than using a highly regulated HCRH, lead. This lack of documentation of successful endeavors points to the need to raise internal awareness and to improve communications as our pollution prevention program becomes more mature. Positive achievements should be recognized to encourage successful actions and to share control techniques with others. It should be noted that more visible efforts of substitution have taken place in the division in the past. An example of a well-publicized effort (internally) was the division-wide substitution of low-hazard insulations for potentially carcinogenic refractory ceramic fiber insulations.

\subsection{POTENTIAL WASTE MINIMIZATION/REDUCTION OPTIONS IDENTIFIED AND SCREENED}

Since HCRH chemicals are diverse and widely used, an exhaustive study for each chemical was not within the scope of the study. General methods for controlling these materials were evaluated, and regulations specific to these chemicals were considered. While these chemicals are generally regulated by the EPA, many are also the subject of specific, detailed occupational standards (e.g., benzene, lead, formaldehyde, beryllium, and arsenic). The occupational regulations do not specifically impact waste generation. The additional 
regulations do impact the cost of working with these materials, and that factor adds importance to minimizing the use of these materials.

The primary focus of this study was placed on identifying generic tools/resources that would help the division to be more efficient in selecting and using chemicals. Table 6 lists potential options and rationale related to controlling HCRH chemicals.

\subsection{POLLUTION PREVENTION AND WASTE MINIMIZATION/ REDUCTION OPTIONS EVALUATED}

Detailed analyses of individual waste streams were not carried out. General operations were considered. Detailed information on individual HCRH waste streams and their cost was not readily available. Detailed goals should be established by groups for specific waste streams. The Division Director should provide resources and encouragement to the groups.

Substitution of less hazardous materials should be feasible in many cases. Less regulated solvent, such as ethanol, or product mixtures, such as Opticlean or Water Chaser 140 solvent, may be substituted for methanol or acetone in some general applications. Ferrous counterweights may be acceptable substitutes for lead. Bismuth may be substituted for lead in some R\&D.applications (as noted previously). Attention should be placed on substitutions for more toxic HCRH materials such as benzene and carbon tetrachloride. The resources or tools necessary to identify HCRH materials and their substitutes should be made available.

Minimization of quantities of $\mathrm{HCRH}$ materials should start at the planning stage and be considered in the procurement of chemicals. It is feasible to do a better job of maintaining minimum inventories of HCRH, and cost savings will be realized, if not in the procurement phase, in the waste handling and disposal part of the life-cycle of the chemicals.

To some extent recycling is practiced for HCRH materials by the division. It should be maximized where feasible.

\subsection{POLLUTION PREVENTION AND WASTE MINIMIZATION/ REDUCTION OPTIONS RECOMMENDED}

To ensure that the division is maximizing its efforts to find substitutes for $\mathrm{HCRH}$, the following actions should be considered:

- Group leaders should understand which chemicals are HCRH materials; lists cross referenced to their inventories should be provided.

- Waste minimization/pollution prevention focus should be applied to proposed new work and existing activities. 
Table 6. Potential waste minimization and reduction options for Metals and Ceramics Division human carcinogens and reproductive hazards

\begin{tabular}{|c|c|c|}
\hline $\begin{array}{l}\text { Potential waste } \\
\text { minimization/ } \\
\text { reduction option }\end{array}$ & $\begin{array}{l}\text { Waste } \\
\text { minimization/ } \\
\text { reduction } \\
\text { technique }\end{array}$ & Feasibility considerations \\
\hline $\begin{array}{l}\text { Replace HCRHa } \\
\text { materials with } \\
\text { non-HCRH } \\
\text { materials, in } \\
\text { proposed work } \\
\text { as well as on- } \\
\text { going R\&Db } \\
\text { activities }\end{array}$ & $\begin{array}{l}\text { Material } \\
\text { substitution/ } \\
\text { process } \\
\text { modification }\end{array}$ & $\begin{array}{l}\text { For many activities this is feasible, but not for all. In some } \\
\text { situations, the use of an HCRH is required. For general } \\
\text { laboratory use of solvents, substitution of less hazardous } \\
\text { solvents should be feasible. Process modification for the } \\
\text { use of solvents for cleaning could result in less hazardous } \\
\text { waste (e.g., use of ethanol on wipes instead of acetone or } \\
\text { methanol reduces the amount of liquid/solid-type mixed } \\
\text { waste.) } \\
\text { The use of lead as counterweights should present a good } \\
\text { potential for substitution. The use of lead for RADe } \\
\text { shielding is not a good candidate for substitution. }\end{array}$ \\
\hline $\begin{array}{l}\text { Reuse/recycle of } \\
\text { HCRH }\end{array}$ & Reuse/recycle & $\begin{array}{l}\text { Most scrap metal is being stored for future recycle. Due to } \\
\text { the low amount of use of general laboratory solvents, this } \\
\text { usage may not be generally open to reuse. Under most } \\
\text { circumstances, lead should be recycled. Photographic } \\
\text { chemicals (containing formaldehyde) are not good } \\
\text { candidates for recycle. }\end{array}$ \\
\hline $\begin{array}{l}\text { Collection of } \\
\text { HCRH materials } \\
\text { in separate } \\
\text { containers }\end{array}$ & Segregation & $\begin{array}{l}\text { Segregation of HCRH materials should be (and is normally) } \\
\text { carried out when feasible. For example, lead or beryllium } \\
\text { materials are normally labeled and segregated. Highly toxic } \\
\text { materials such as carbon tetrachloride or benzene should be } \\
\text { segregated from other laboratory chemicals during their life- } \\
\text { cycle to the extent feasible (as required by DOEd Order } \\
5480.10 \text { ). }\end{array}$ \\
\hline $\begin{array}{l}\text { Minimize the } \\
\text { purchase and } \\
\text { storage of } \\
\text { HCRH } \\
\text { chemicals to the } \\
\text { quantities } \\
\text { necessary to } \\
\text { perform tasks }\end{array}$ & $\begin{array}{l}\text { Waste } \\
\text { minimization }\end{array}$ & $\begin{array}{l}\text { Experiment/work requirements should be scrutinized prior } \\
\text { to ordering chemicals to ensure that the minimum amount of } \\
\text { these materials is ordered. Inventories should be evaluated } \\
\text { periodically to ensure that stocks of HCRH materials are } \\
\text { kept as low as is reasonable. The expectation of carrying } \\
\text { out minimization would be more realistic if systems like } \\
\text { AVIDe and HMISS were dedicated to assist staff members in } \\
\text { carrying out minimization activities. Criticisms of these } \\
\text { systems were presented to ORNL's Fix-It Committee by the } \\
\text { division. }\end{array}$ \\
\hline
\end{tabular}

aHRCH $=$ human carcinogens and reproductive hazards.

$b R \& D=$ research and development.

$c \mathrm{RAD}=$ radioactive.

$c D O E=$ U.S. Deparment of Energy.

eAVID = Accelerated Vendor Inventory Delivery System.

fHMIS = Hazardous Materials Inventory System.

$8 \mathrm{ORNL}=$ Oak Ridge National Laboratory. 
- The division staff should be made aware of generic substitutes and of the principles of substitution as a control methodology.

- The division staff should be made aware of the need to limit the procurement and storage of HCRH materials to the amount needed to perform work. Efforts to have data systems improved to meet our needs should continue.

- Group leaders should set yearly waste minimization goals for HCRH materials, and an overall division goal for reduction in HCRH should be set by the Division Director. 


\section{.}




\section{OFFICE AND MISCELLANEOUS WASTE MINIMIZATION TEAM ACTIVITIES}

The M\&C Program established the following mission for this team:

Materials such as white paper, aluminum cans, and cardboard boxes make up a significant volume of the division waste. While these materials are not hazardous, minimizing waste has many beneficial effects. This team is chartered to study all aspects of the use and disposal of these materials necessary to develop recommendations to ensure waste minimization to the extent that is reasonable. The team must be aware of pertinent community initiatives to ensure that recommendations are consistent and supportive of other waste minimization efforts. Where possible, the team should provide quantitative/cost information related to current waste generation, controls, and waste generation after implementation of the team's recommendations. The team should provide information and suggestions needed to increase the involvement of the division in waste minimization.

Based on this mission and guidance provided by M\&C management, the Office and Miscellaneous Waste Minimization Team started evaluating the sources of these waste streams, the waste characteristics, potential minimization and reduction options, cost associated with managing the waste and of various waste minimization options, and developing a recommended strategy for minimizing these waste streams.

\subsection{DESCRIPTION OF OFFICE AND LABORATORY OPERATIONS GENERATING OFFICE AND MISCELLANEOUS WASTE}

The M\&C Division generates a multitude of office and miscellaneous wastes with the most visible waste streams being waste paper, aluminum cans, toner cartridges, cardboard, pallets, and excess equipment. The waste paper is generated from office activities such as writing and typing documents and discarding mail such as vendor catalogs. It was indicated to the team that the aluminum cans generated by employees are (might be) the property of the employee, while all the rest of this waste category belongs to DOE. Waste toner cartridges are generated by users of computer printers. Waste cardboard is generated from packages received by the division, including those used for copier and printer paper and equipment. Pallets are generated when large items are received by the division, such as large equipment. The excess property is generated when a laboratory is remodeled for a new project and old equipment no longer needed is excessed or when old office furniture is replaced. 


\subsection{WASTE CHARACTERIZATION}

Because M\&C activities are spread across ORNL and are located in buildings shared with other divisions, exact quantities of this waste type generated by the M\&C Division are not available. However, based on process and activity knowledge, this waste type is deemed nonradioactive and nonhazardous.

\subsection{POTENTIAL WASTE MINIMIZATION/REDUCTION OPTIONS IDENTIFIED AND SCREENED}

Several potential waste minimization and reduction options were identified and screened. Each option was screened based on technical feasibility, research operations feasibility, and environmental compliance impacts. Table 7.lists these potential options and gives reasons for eliminating or further evaluating specific options.

\subsection{POLLUTION PREVENTION AND WASTE MINIMIZATION/ REDUCTION OPTIONS EVALUATED}

Detailed evaluations of specific options and associated costs were not developed by the team. Most options, such as that of enhanced participation in existing ORNL recycling programs and increased participation in the Adopt-A-School Program, should be of low cost. Participation in more comprehensive recycle programs would require some effort from the division staff.

The general team recommendation is for a division steering committee to be established to enhance the entire staff's awareness of pollution prevention efforts and to help the Division Director establish worthwhile goals.

\subsection{POLLUTION PREVENTION AND WASTE MINIMIZATION/ REDUCTION OPTION(S) RECOMMENDED}

Ongoing studies of division activities should be supported. In the future, as specific detailed recommendations are made, they should be considered for adoption by the Division Director. It is recommended that a rechartered team to study miscellaneous nonhazardous wastes be established to develop detailed information on division participation in existing recycle efforts and to make detailed recommendations for other worthwhile projects. Finally, it is recommended that the Division Director consider establishing a steering committee for pollution prevention to evaluate progress and make recommendations for the pollution prevention/waste minimization efforts. 
Table 7. Potential waste minimization and reduction options for Metals and Ceramics Division office and miscellaneous wastes

\begin{tabular}{|c|c|c|}
\hline $\begin{array}{l}\text { Potential waste } \\
\text { minimization/ } \\
\text { reduction option }\end{array}$ & $\begin{array}{l}\text { Waste } \\
\text { minimization/ } \\
\text { reduction technique }\end{array}$ & Feasibility considerations \\
\hline $\begin{array}{l}\text { Survey of paper/ } \\
\text { miscellaneous } \\
\text { materials usage } \\
\text { and paper/ } \\
\text { miscellaneous } \\
\text { waste generation }\end{array}$ & Not applicable & $\begin{array}{l}\text { Because usage and generation values are not readily } \\
\text { available, a survey could be used to gather this } \\
\text { information. This information would then allow the } \\
\text { division to further evaluate potential minimization and } \\
\text { reduction options. This study will continue to } \\
\text { evaluate this option. }\end{array}$ \\
\hline $\begin{array}{l}\text { Pilot of mixed } \\
\text { waste paper } \\
\text { collection in } \\
\text { M\&Ca Division } \\
\text { for use in aqua } \\
\text { seeding system }\end{array}$ & Recycle/reuse & $\begin{array}{l}\text { The current white paper recycle is limited to areas where } \\
\text { no work involving radioactive materials is performed, } \\
\text { based on liability rather than actual contamination. } \\
\text { However, there is a great deal of waste paper from these } \\
\text { areas that is not contaminated and could be recycled on- } \\
\text { site. ORNL has procured an aqua seeder system that } \\
\text { takes waste paper, pulps it, and then mixes it with grass } \\
\text { seed. This mixture is sprayed on hillsides and other } \\
\text { areas as a way to seed and stabilize bare soil areas. This } \\
\text { study will continue to evaluate this option. }\end{array}$ \\
\hline $\begin{array}{l}\text { Electronic } \\
\text { messaging and } \\
\text { routing }\end{array}$ & $\begin{array}{l}\text { Process } \\
\text { modification/ } \\
\text { substitution }\end{array}$ & $\begin{array}{l}\text { To reduce paper usage, electronic messaging or routing } \\
\text { could be utilized to replace regular copied and mailed } \\
\text { items such as division staff meeting minutes, } \\
\text { management reports, miscellaneous memorandums, } \\
\text { organizational announcements, and seminar notices. } \\
\text { This study will continue to evaluate this } \\
\text { option. }\end{array}$ \\
\hline $\begin{array}{l}\text { Aluminum can } \\
\text { recycle }\end{array}$ & Recycle/reuse & $\begin{array}{l}\text { Based on a survey of the division, take steps to enhance } \\
\text { voluntary division participation. Communicate actions to } \\
\text { the ORNL } b \text { Waste Minimization Coordinator. }\end{array}$ \\
\hline $\begin{array}{l}\text { Pallet } \\
\text { replacement/ } \\
\text { recycle }\end{array}$ & $\begin{array}{l}\text { Material } \\
\text { substitution/ } \\
\text { recycle/reuse }\end{array}$ & $\begin{array}{l}\text { Suggest the possibility of using reusable plastic or metal } \\
\text { pallets instead of wooden ones or the possibility of } \\
\text { sending unusable ORNL pallets to Y-12 to be mulched, } \\
\text { or get a chipper system for ORNL. Communicate } \\
\text { actions to the ORNL Waste Minimization Coordinator. }\end{array}$ \\
\hline
\end{tabular}


Table 7. (Continued)

\begin{tabular}{|l|l|l|}
\hline $\begin{array}{l}\text { Potential waste } \\
\text { minimization/ } \\
\text { reduction option }\end{array}$ & $\begin{array}{l}\text { Waste } \\
\text { minimization/ } \\
\text { reduction technique }\end{array}$ & \multicolumn{1}{|c|}{ Feasibility considerations } \\
\hline $\begin{array}{l}\text { Adopt-A- } \\
\text { School program }\end{array}$ & Recycle/reuse & $\begin{array}{l}\text { Based on a survey of the division, take steps to enhance } \\
\text { voluntary division participation. Communicate actions to } \\
\text { the ORNL Waste Minimization Coordinator. }\end{array}$ \\
\hline $\begin{array}{l}\text { Toner cartridge } \\
\text { recycle program }\end{array}$ & Recycle/reuse & $\begin{array}{l}\text { Based on a survey of the division, take steps to enhance } \\
\text { voluntary division participation. Communicate actions to } \\
\text { the ORNL Waste Minimization Coordinator. }\end{array}$ \\
\hline Swap Shop & Recycle/reuse & $\begin{array}{l}\text { Encourage divisional participation in the Swap Shop } \\
\text { through promotional activities such as an article in the } \\
\text { divisional newsletter or a presentation and question and } \\
\text { answer session with the Swap Shop Coordinator at a } \\
\text { safety meeting. }\end{array}$ \\
\hline
\end{tabular}

$a \mathrm{M} \& \mathrm{C}=$ Metals and Ceamics Division.

bORNL = Oak Ridge National Laboratory. 


\section{PHOTOGRAPHIC WASTE MINIMIZATION TEAM ACTIVITIES}

The M\&C Program established the following mission for this team:

Photographic wastes make up a significant part of the division's hazardous waste. This team is chartered to study all aspects of the use and disposal of these materials necessary to develop recommendations and to ensure waste is minimized to the extent that is reasonable. The team must be aware of pertinent regulations to ensure that recommendations are compliant. Where possible, the team should provide quantitative/cost information related to current waste generation, controls, and waste generation after implementation of the team's recommendations.

Based on this mission and guidance provided by M\&C management, the Photographic Waste Minimization Team started evaluating the sources of these waste streams, the waste characteristics, potential minimization and reduction costs associated with managing the waste and various waste minimizaation options, and developing a recommended strategy for minimizing these waste streams. EPA guidance ${ }^{2}$ and a PWA performed by ORNL 6 in 1992 were used as references for this study.

\subsection{DESCRIPTION OF LABORATORY OPERATIONS GENERATING PHOTOGRAPHIC WASTE}

M\&C Central Photography was determined to generate approximately $90 \%$ of the photographic waste deemed RCRA hazardous waste. This waste consists of photographic chemicals such as stabilizer, short stop, activator, bleach/fixer, fixer, developer, and developer/fixer. This area also generates rinse water that contains traces of these chemicals, including silver from the fixer.

\subsection{WASTE CHARACTERIZATION}

This waste is not radioactively contaminated, and the total quantity generated, excluding the rinse water in CY 1992, was approximately $7500 \mathrm{lb}$. Information provided to the study team indicated that associated handling costs are approximately $\$ 15,000$. The spent photographic chemicals are collected in containers ranging in size from bottles to drums. The rinse water is discharged to the process drain as process waster. No chemical analysis is performed on any of these wastes. The spent photochemicals are currently picked up by the WMRAD and taken to storage. The rinse water is treated as process waste and discharged through an NPDES-permitted discharge. 


\subsection{POTENTIAL WASTE MINIMIZATION/REDUCTION OPTIONS IDENTIFIED AND SCREENED}

Several potential waste minimization and reduction options were identified and screened. Each option was screened based on technical feasibility, research operations feasibility, and environmental compliance impacts. Table 8 lists these potential options and gives reasons for eliminating or further evaluating specific options.

\subsection{POLLUTION PREVENTION AND WASTE MINIMIZATION/ REDUCTION OPTIONS EVALUATED}

The potential photographic waste minimization options that were further evaluated are listed below with additional purchase equipment cost information as appropriate:

\section{Option}

Photographic imaging

Metallic replacement canisters
Purchased equipment cost

$\$ 30,000$ to $\$ 100,000$

$\$ 200$ installation $\$ 200 / 6$ months for cartridge $\$ 200 / 6$ months for silver
Comment

Eliminates all hazardous waste generation from Central Photography

Would still have some hazardous waste generated by photographic operations

\subsection{POLLUTION PREVENTION AND WASTE MINIMIZATION/ REDUCTION OPTION(S) EVALUATED}

Though the photoimaging through digitization option initially appears to be rather expensive when compared to the canisters, it would eliminate all chemical waste generation from the photoprocessing areas and would have the added advantage of improving storage and editing of images. The quality of film negatives gradually diminishes with time, while as long as a diskette is not damaged, the electronic data stored maintain their integrity. The team recommends that the $M \& C$ Division invest enough, approximately $\$ 30,000$, in equipment to initially set up a basic system in the M\&C Central Photography area. After a 6-month trial period to ensure that system is reliable and produces quality images, the team recommends gradual procurement of additional equipment and networking the system to maximize the efficiency and output. This will ultimately eliminate all chemicals from the photoprocessing area. The team also recommends that all users of this system attend a basic training course to ensure that the system is used properly.

In the interim, until digitization equipment is procured and the photographic areas are completely converted, the study team recommends that the metallic replacement canisters be 
Table 8. Potentail waste minimization and reduction options for Metals and Ceramics Division photographic wastes

\begin{tabular}{|c|c|c|}
\hline $\begin{array}{l}\text { Potential waste } \\
\text { minimization/ } \\
\text { reduction option }\end{array}$ & $\begin{array}{l}\text { Waste } \\
\text { minimization/ } \\
\text { reduction } \\
\text { technique }\end{array}$ & Feasibility considerations \\
\hline $\begin{array}{l}\text { Photographic } \\
\text { waste } \\
\text { generation } \\
\text { pperations } \\
\text { shutdown }\end{array}$ & Not applicable & $\begin{array}{l}\text { This option is not feasible because operations generating } \\
\text { photographic wastes are vital for documenting and analyzing } \\
\text { research being performed. This option will not be considered } \\
\text { further. }\end{array}$ \\
\hline Photoimaging & $\begin{array}{l}\text { Process } \\
\text { modification/ } \\
\text { material } \\
\text { substitution }\end{array}$ & $\begin{array}{l}\text { Photographic imaging techniques are already being used in } \\
\text { M\&C }{ }^{a} \text { on a.limited basis at the High Temperature Materials } \\
\text { Laboratory with successful results. This technology would } \\
\text { eliminate all of the hazardous waste generated in developing } \\
\text { film and making prints. The system uses a camera that } \\
\text { contains a diskette instead of film. The study team will } \\
\text { continue to evaluate this option. }\end{array}$ \\
\hline $\begin{array}{l}\text { Silver recovery } \\
\text { from fixer using } \\
\text { metallic } \\
\text { replacement } \\
\text { (canisters) }\end{array}$ & Recycle/reuse & $\begin{array}{l}\text { The ORNL } b \text { Waste Minimization/Reduction Pollution } \\
\text { Prevention Program is currently performing a pilot of these } \\
\text { cartridges in the Solid State Division. The results, to date, } \\
\text { appear to be successful in meeting the RCRAc hazardous } \\
\text { waste limit of }<5 \text { ppmd of silver. Two canisters are installed } \\
\text { in series in the discharge line and exchange iron ions from the } \\
\text { steel wool in the canisters for silver ions in the solution. The } \\
\text { silver in the canisters can then be recovered by an off-site } \\
\text { vendor. The study team will continue to evaluate } \\
\text { this option. }\end{array}$ \\
\hline $\begin{array}{l}\text { Electrolytic silver } \\
\text { recovery from } \\
\text { fixer }\end{array}$ & Recycle/reuse & $\begin{array}{l}\text { Though this method recovers silver as a pure metal, there is a } \\
\text { potential for sulfide formation and usually a high silver } \\
\text { concentration in the effluent. This option is not practical for } \\
\text { the relatively small photographic operations in the M\&C } \\
\text { Division. This option will not be considered further. }\end{array}$ \\
\hline $\begin{array}{l}\text { Chemical } \\
\text { precipitation of } \\
\text { silver from fixer }\end{array}$ & Recycle/reuse & $\begin{array}{l}\text { While this option can attain } 0.1 \mathrm{mg} / \mathrm{L} \text { of silver in the effluent } \\
\text { and requires low investment, it is a complex operation that } \\
\text { recovers the silver as a sludge with the potential for releasing } \\
\text { hydrogen sulfide. This method is not practical for the M\&C } \\
\text { Division due to the relatively small quantity of waste } \\
\text { generated and because this precipitation step could be } \\
\text { interpreted as treatment under RCRA. This option will not be } \\
\text { considered further. }\end{array}$ \\
\hline $\begin{array}{l}\text { Silver recovery } \\
\text { from rinse water } \\
\text { using ion } \\
\text { exchange }\end{array}$ & Recycle/reuse & $\begin{array}{l}\text { The silver-thiosulfate complex has a high affinity for the ion } \\
\text { exchange resin and can prevent recovering the silver and } \\
\text { regenerating the resin. The resin can also plug with } \\
\text { suspended matter from the photoprocessing activities. This } \\
\text { option is not practical for the M\&C Division due to the } \\
\text { relatively small quantity of waste generated. This option will } \\
\text { not be considered further. }\end{array}$ \\
\hline
\end{tabular}


Table 8. (Continued)

\begin{tabular}{|c|c|c|}
\hline $\begin{array}{l}\text { Potential waste } \\
\text { minimization/ } \\
\text { reduction option }\end{array}$ & $\begin{array}{l}\text { Waste } \\
\text { minimization/ } \\
\text { reduction } \\
\text { lechnique }\end{array}$ & Feasibility considerations \\
\hline $\begin{array}{l}\text { Silver recovery } \\
\text { from rinse water } \\
\text { using reverse } \\
\text { osmosis }\end{array}$ & Recyclefreuse & $\begin{array}{l}\text { This option requires more capital costs than other recovery } \\
\text { methods, and silver must be recovered from the concentrate } \\
\text { produced from this method. Reverse osmosis is not practical } \\
\text { for the M\&C Division due to the relatively small quantity of } \\
\text { waste generated. This option will not be considered further. }\end{array}$ \\
\hline $\begin{array}{l}\text { Silver rocovery } \\
\text { from scrap }\end{array}$ & Recycle/reuse & $\begin{array}{l}\text { This option would require sending waste off-site and would } \\
\text { not be practical for the small quantity of waste generated. } \\
\text { This option will not be considered further. }\end{array}$ \\
\hline $\begin{array}{l}\text { Countercurrent } \\
\text { finsing }\end{array}$ & Recycie/reuse & $\begin{array}{l}\text { This option is usually used on continuous photoprocessing } \\
\text { lines. It is not practical for the M\&C Division due to the batch } \\
\text { mode of operations and the relatively small quantity of waste } \\
\text { generated. This option will not be considered further. }\end{array}$ \\
\hline Evaporation & Recycle/reuse & $\begin{array}{l}\text { The team evaluated the evaporator in the Graphies Division. } \\
\text { This method does minimize the aqueous effluent and can } \\
\text { conserve water, however, it requires a high level of energy. } \\
\text { The silver is recovered as a sludge, and there is a potential for } \\
\text { air emissions. This option is not practical for the M\&C } \\
\text { Division due to the relatively small quantity of waste } \\
\text { generated. This option will not be considered further. }\end{array}$ \\
\hline $\begin{array}{l}\text { Color developer } \\
\text { reuse }\end{array}$ & Recycie/reuse & $\begin{array}{l}\text { While color developers are available that can be regenerated, } \\
\text { some processes require ion exchange to remove by-products } \\
\text { and others do not However, due to the relatively small } \\
\text { quantities of color photographic developer used by the M\&C } \\
\text { Division, this option is not practical. This option will not be } \\
\text { considered further. }\end{array}$ \\
\hline
\end{tabular}

aMetals and Ceramies Division.

bORNL = Oak Ridge National Laboratory.

$c \mathrm{RCRA}=$ Resource Conservation and Recovery Act.

$₫$ ppm = parts per million.

installed at M\&C Central Photography in order to recover the silver from the fixer. Once the silver is removed from this waste stream by the canisters, it is no longer an RCRA characteristic waste since the concentration is below $5 \mathrm{mg} / \mathrm{L}$.

Smaller sources of photographic waste should be studied individually to determine if the waste is being minimized and if it is being handled in the most efficient way. 
The state-of-the-art technology for photography is digital photoimaging. Conversion to this technology occurred in limited areas of the division. This team study helped circulate information and generate further interest. Communications within the division between those performing photographic processing should be arranged. The entire division can share information and equipment. The team recommends that a second team be established composed of the division's photographic processors. 
, 


\section{SUMMARY OF RECOMMENDED OPTIONS}

The team studies generated multiple alternatives for waste stream minimization. Some of the solutions will require further detailed evaluations of pilot systems, while others are straightforward.

Minimization of the used oil generated by the division is the most complex of those detailed by the empowered teams. Further team studies are proposed to evaluate extending the life of hydraulic fluids, to evaluate the use of oilless vacuum systems, to evaluate the use of the division's oil for fuel in heaters, and to look at ways to reduce the significant cost of sampling and analysis of used oils.

Similarly, additional team work is proposed for studying miscellaneous nonhazardous wastes in the division. Further studies of the division staff's participation in pollution prevention, development of cost-benefit data associated with the staff's increased involvement in waste minimization programs, and development of potential pollution prevention goals for the division should be performed by a rechartered group. It is also recommended that a division pollution prevention steering committee be considered by division management. This group would be composed of a cross section of the division staff and would evaluate and make recommendations related to the division's pollution prevention program.

Solutions for the primary sources of waste acids and photographic wastes are straightforward and should be instituted by the groups that generate the majority of these wastes with technical assistance by the division ESH Group. After approval is obtained to neutralize (acids) and to filter silver (photographic) from these streams, new methods for handling these wastes should be instituted. The long-term solution to photographic wastes is conversion to digital processing, which is now considered to be state-of-the-art technology. The division should pursue this technology and use pollution prevention (and the benefits from pollution prevention) as a factor in selecting new equipment.

The reduction in building exhaust filters on Building 4508, as a team recommendation, represents a method to reduce both waste and energy. Implementation of the team's minimization proposal will require the involvement of specialty disciplines such as mechanical engineers and ESH professionals. The effort should be integrated with the division's energy reduction efforts that are currently under way.

Finally, minimization of hazardous chemicals, human carcinogens, and reproductive toxins requires involvement of all those engaged in research in the division. To initiate awareness, the ESH Group should develop administrative and technical tools to facilitate and focus the division's efforts. 
Success in pollution prevention will result in numerous benefits to the division. The current systems do not adequately account for the costs of waste generation. It is predictable that, in the future, our customers will recognize and make demands for conservation of our resources. The teamwork performed in the area of waste minimization will plant the seeds that will help the division to have continuous improvement in the area of pollution prevention. 


\section{ACKNOWLEDGMENTS}

The efforts of the M\&C Division Empowered Teams (see Table 1), without whose assistance this waste minimization/pollution prevention study could not have been completed, are gratefully acknowledged by the Division Director. Special thanks also go to M. R. Upton for final manuscript preparation, K. Spence for editing, and G. R. Carter for quality assurance review. 



\section{REFERENCES}

1. U.S. Department of Energy, Model Process Waste Assessment Plan, prepared by Hazardous Waste Remedial Actions Program (HAZWRAP), Jan. 15, 1991.

2. U.S. Environmental Protection Agency, Guides to Pollution Prevention in the Bhotoprocessing Industry, EPA/626/7-9012, Washington, D.C., October 1991.

3. U.S. Environmental Protection Agency, Facility Pollution Prevention Guide, HEPA/600/R-92/088, Washington, D.C., May 1992.

4. Martin Marietta Energy Systems, Inc., Oak Ridge National_Laboratory Waste Management Plan, ORNL/TM-11433/R2, December 1992.

5. Martin Marietta Energy Systems, Inc., Y-12 Waste Management Division Process Waste Assessment (PWA) Report, Y/SUB/WM-0099, January 1992.

6. Martin Marietta Energy Systems, Inc., Oak Ridge National Laboratory Photoprocessing Facilities Process Waste Assessment. X-OE-635, September 1992. 

APPENDIX A

MARTIN MARIETTA ENERGY SYSTEMS, INC. (MMES) TENTATIVE PRIMARY REPRODUCTIVE TOXINS LISTING 
-

, 
This is a proposed priority listing of reproductive hazards for workplace hazard evaluation and assignment of RREI's. The MMES MSDS system will include an expanded list which should be consulted for hazard communication purposes.

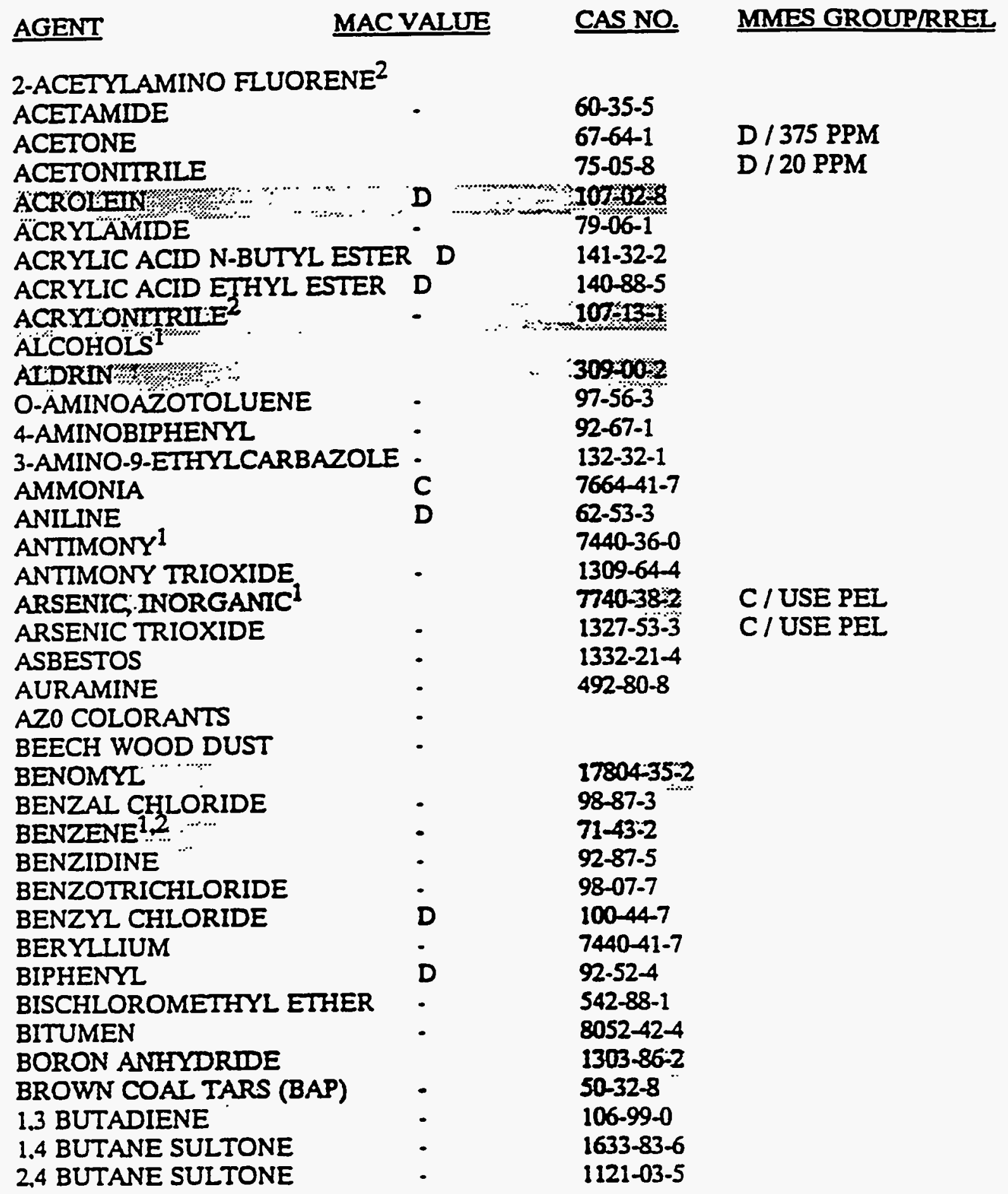




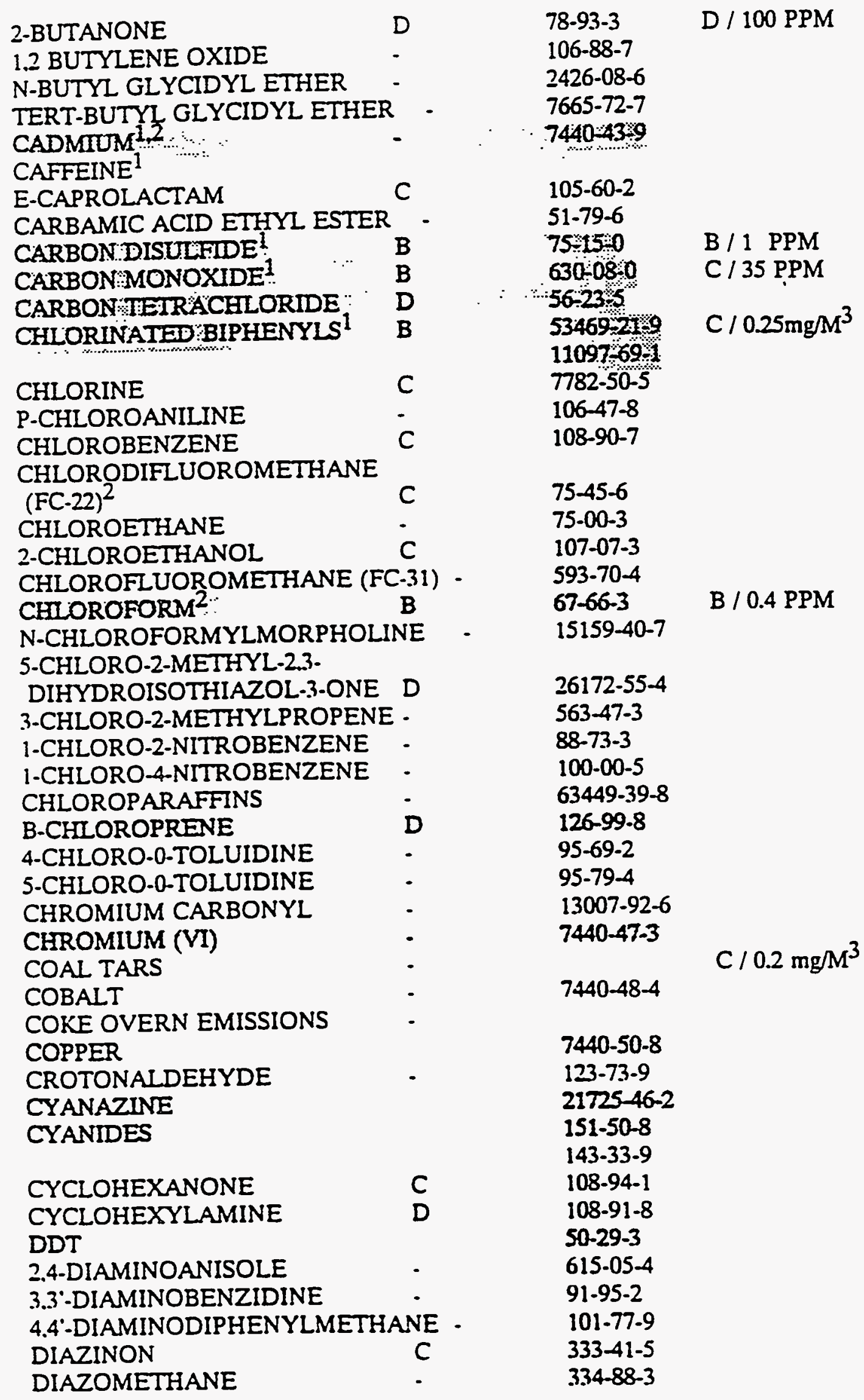




\begin{tabular}{|c|c|c|c|}
\hline \multicolumn{2}{|c|}{ 1,ZDIBROMO3:CHLOROPROPANE - } & \\
\hline 1.2-DIBROMOETHANE & - & $106-934$ & \\
\hline DI:N=BUTYYPETHALATE & & 84742 & -- \\
\hline DICHLOROACEIYLENE & - & $7572-29-4$ & -- \\
\hline 1.2-DICHLOROBENZENE & C & $95-50-1$ & \\
\hline 1.4-DICHLOROBENZENE & C & $106-46-7$ & \\
\hline 3,3'-DICHLOROBUTENE-2 & - & $764-41-0$ & \\
\hline $\begin{array}{l}\text { DICHLORODIFLUOROMETHAN, } \\
\text { (FC-12) }\end{array}$ & & & \\
\hline $\begin{array}{l}\text { (FC-12) } \\
\text { 1.1-DICHLOROETHANE }\end{array}$ & C & $75-71-8$ & \\
\hline $\begin{array}{l}\text { 1.1-DICHLOROETHANE } \\
\text { 1,2-DICHLOROETHANE }\end{array}$ & D & $75-34-3$ & C / 50 PPM \\
\hline $\begin{array}{l}\text { 1,2-DICHLOROETHANE } \\
2,2^{\prime} \text {-DICHLOROETHYL SULFIDE }\end{array}$ & - & $107-06-2$ & C / 0.5 PPM \\
\hline $\begin{array}{l}\text { 2,2'-DICHLOROETHYL SULFIDE } \\
\text { DICHIOROMETHANE }\end{array}$ & & $505-60-2$ & \\
\hline $\begin{array}{l}\text { DICHIOROMETHANE } \\
\text { 1,2-DICHLOROMETHOXYETHAN }\end{array}$ & $D$ & $75: 09=2$ & $\mathrm{~B} / 50 \mathrm{mg} / \mathrm{M}^{3}$ \\
\hline $\begin{array}{l}\text { 1,2-DICHLOROMETHOXYETHAI } \\
\text { 1,3-DICHLORO-2-PROPANOL }\end{array}$ & E - & $41683-62-9$ & \\
\hline 1.3-DICHLORO-2-PROPANOL & - & $96-23-1$ & \\
\hline 1.3-DICHLOROPROPENE & - & $542-75-6$ & \\
\hline $\begin{array}{l}\text { DICHLORVOS } \\
\text { DIELDRIN }\end{array}$ & C & $62-73-7$ & \\
\hline $\begin{array}{l}\text { DIELDRIN } \\
\text { DIESEL ENGINE EMISSIONS }\end{array}$ & & $60-57.1$ & \\
\hline $\begin{array}{l}\text { DIESEL ENGINE EMISSIONS } \\
\text { DIETHYLCARBAMOYL CHLORI }\end{array}$ & - & & \\
\hline $\begin{array}{l}\text { DIETHYICARBAMOYL CHLORI } \\
\text { DI(2-ETHYLHEXYL)PHTHALATI }\end{array}$ & DE & $88-10-8$ & \\
\hline $\begin{array}{l}\text { DI(2-ETHYLHEXYL)PHTHALATF } \\
\text { DIETHYL SULFATE }\end{array}$ & $c$ & $117-81-7$ & \\
\hline $\begin{array}{l}\text { DIETHY SULFATE } \\
\text { 1.1-DIFLUOROETHYLENE }\end{array}$ & - & $64-67-5$ & \\
\hline $\begin{array}{l}\text { 1.1-DIFLUOROETHYLENE } \\
\text { 3.3'-DIMETHOXYBENZIDINE }\end{array}$ & - & $75-38-7$ & \\
\hline 3.3'-DIMETHOXYBENZIDINE & - & $119-90-4$ & \\
\hline 1.2-DIMETHOXYETHANE ${ }^{2}$ & & $110-71-4$ & \\
\hline N.N-DIMETHYLACEIAMIDE ${ }^{2}$ & C & $127-19-5$ & \\
\hline $\begin{array}{l}\text { 4-DIMETHYLAMINOBENZENE }{ }^{2} \\
\text { DIMETHYLCARBAMOYL CHLO }\end{array}$ & & $1300-73-8$ & \\
\hline $\begin{array}{l}\text { DIMETHYLCARBAMOYL CHLOI } \\
\text { DIMETHYL ETHER }\end{array}$ & RIDE & $79-44-7$ & \\
\hline 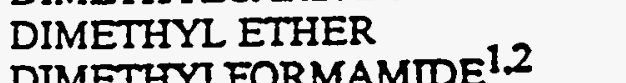 & D & $115-10-6$ & \\
\hline $\begin{array}{l}\text { DIMETHYIFORMAMIDE } 1.2 \\
\text { 11-DIMETHYLHYRAZINE }\end{array}$ & B & $68-12-2$ & \\
\hline 1.1-DIMETHYLHYDRAZINE & - & $57-14-7$ & \\
\hline 1.2-DIMETHYLHYDRAZINE & - & $540-73-8$ & \\
\hline DIMETHYL HYDROGEN PHOSP & HITE & $868-85-9$ & \\
\hline DIMETHYLSULFAMOYL CHLOR & IDE - & $1.3 .360-57-1$ & \\
\hline DIMETHYL SULFATE, & - & $77-78-1$ & \\
\hline DIMETHYL SULFOXIDE ${ }^{2}$ & & $67-68-5$ & \\
\hline DINITROBENZENE & - & $25154-54-5$ & \\
\hline DINITRONAPHTHALENES & - & $27478-34-8$ & \\
\hline DINITROTOLUENES & - & $25321-14-6$ & \\
\hline DINOSEB & & $88-85-7$ & \\
\hline 1.4-DIOXANE & D & $123.91-1$ & \\
\hline DURSBAN & & $2921-88-2$ & $\mathrm{D} / 0.1 \mathrm{mg} / \mathrm{M}^{3}$ \\
\hline ENDRIN & & $72-20-8$ & \\
\hline ENFLURANE & & $13838-16-9$ & \\
\hline EPICHLOROHYDRIN & - & $106-89-8$ & \\
\hline ETHANOL & D & $6+17-5$ & D / 500 PPM \\
\hline ETHYLENEDIAMINE & D & $107-15-3$ & \\
\hline ETHYLENE DIBROMIDE & & $106-93-4$ & \\
\hline ETHYLENE GLYCOL & C & $107-21-1$ & \\
\hline
\end{tabular}




\begin{tabular}{|c|c|c|c|}
\hline \multirow{2}{*}{\multicolumn{4}{|c|}{$\begin{array}{lc}\text { ETHER } & C \\
\text { ETHYLENE GLYCOL MONOBUTYL }\end{array}$}} \\
\hline & & & \\
\hline ETHER ACETATE & C & $112-07-2$ & C/ 10 PPM \\
\hline \multicolumn{4}{|c|}{ EIHYLENEGIYCOL YONOETHYL } \\
\hline $\operatorname{EIHER}^{12}$ & $B:$ & $\% 11080 \times 5$ & B / 0.1 PPM \\
\hline \multicolumn{4}{|c|}{ ETHYLENE GYYCOLYYONOETHYL } \\
\hline $\begin{array}{l}\text { EIHER ACETATC } \\
\text { EIHYLENE GLYCOL MONOMEI }\end{array}$ & $\mathrm{B}$ \% & $110 \% 496$ & B / 0.1 PPM \\
\hline \multicolumn{4}{|c|}{ EIHYISENE GLYCOL MONOMETHYL } \\
\hline EIHER $12 \%$ & & 109864 & B / 0.1 PPM \\
\hline \multicolumn{4}{|c|}{ ETHYLENE GLYOOL MONOMETHYI. } \\
\hline \multicolumn{2}{|l|}{ ETHER ACEAAATEY } & $110 \% 49 \%$ & B / 0.1 PPM \\
\hline EIHYLENE OXIDE 1 & & 75.21 .8 & \\
\hline $\begin{array}{l}\text { ETHYLENIMINE } \\
\text { ETHYLENE THOUREA }{ }^{2}\end{array}$ & & $151-56-4$ & \\
\hline $\begin{array}{l}\text { ETHYLENE THOUREA } \\
\text { ETHYL ETHER }\end{array}$ & & $96-45-3$ & \\
\hline $\begin{array}{l}\text { ETHYL ETHER } \\
\text { FORMALDEHYDE }\end{array}$ & D & $\begin{array}{l}60-29-7 \\
50-00-0\end{array}$ & \\
\hline $\begin{array}{l}\text { FORMALDEHYDE } \\
\text { FORMAMIDE }^{2}\end{array}$ & C & & \\
\hline FORMIC ACID ETHYL ESTER & D & $109-94-4$ & \\
\hline $\begin{array}{l}\text { FORMIC ACID METHYL ESTER } \\
\text { GLYCIDYL ETHIERS }\end{array}$ & D & \multicolumn{2}{|c|}{ GLYCDYY ETHERS } \\
\hline AIIYL $+?$ & & $106-923$ & \\
\hline$B U T I L)$ । & & $2426.08 \% 6$ & \\
\hline \multicolumn{4}{|c|}{ GLYCIDYI TRIMETHYL AMMONIUM } \\
\hline CHLORIDE & - & $3033-77-0$ & \\
\hline $\begin{array}{l}\text { HALOTHANE } 1 \\
\text { HFP }\end{array}$ & B & $151-67-7$ & \\
\hline \multicolumn{4}{|l|}{ HERBICIDES 1} \\
\hline \multicolumn{2}{|l|}{ HEXACHLOROBENZENE ${ }^{1}$} & $\begin{array}{l}118-7471 \\
87-68-3\end{array}$ & \\
\hline \multicolumn{2}{|l|}{ HEXACHLORO-1,3-BUTADIENE - } & $87-68-3$ & \\
\hline & & $684-16-2$ & \\
\hline \multicolumn{4}{|l|}{ HEXAMETHYLPHOSPHORIC ACID } \\
\hline TRIAMIDE & - & 680-31-9 & \\
\hline HEXANE & C & $110-54-3$ & C/25 PPM \\
\hline HYDRAZINE & - & $302-01-2$ & \\
\hline HYDROGEN CHLORIDE & C & $7647-01-0$ & \\
\hline $\begin{array}{l}\text { HYDROGEN FLUORIDE } \\
\text { INSECTICIDES }\end{array}$ & & $7664-39-3$ & D / $1.5 \mathrm{PPM}$ \\
\hline 2-ISOPROPOXYETHANOL & C & 109-59-1 & \\
\hline ISOPROPYL ALCOHOL & D & $67-63-0$ & \\
\hline ISOPROPYL OIL & - & & \\
\hline KEPONE & - & $143-50-0$ & \\
\hline LEAD 1,2 & B & $7439-92-1$ & $\begin{array}{r}\mathrm{A} /<10 \mathrm{mg} / \mathrm{dl} \\
0.005 \mathrm{mg} / \mathrm{M}^{3}\end{array}$ \\
\hline LEAD CHROMATE & - & $7758-97-6$ & \\
\hline MALATHION & C & $121-75-5$ & \\
\hline MALEIC ACID ANHYDRIDE & C & $108-31-6$ & \\
\hline MANGANESE & & $7439-96.5$ & \\
\hline MAN-MADE MINERAL FIBI & 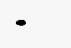 & & \\
\hline MEDICINES, CARCINOGENIC & - & & \\
\hline METAL-WORKING FLUIDS WHI & & & \\
\hline TAIN NITRITE & & & \\
\hline
\end{tabular}




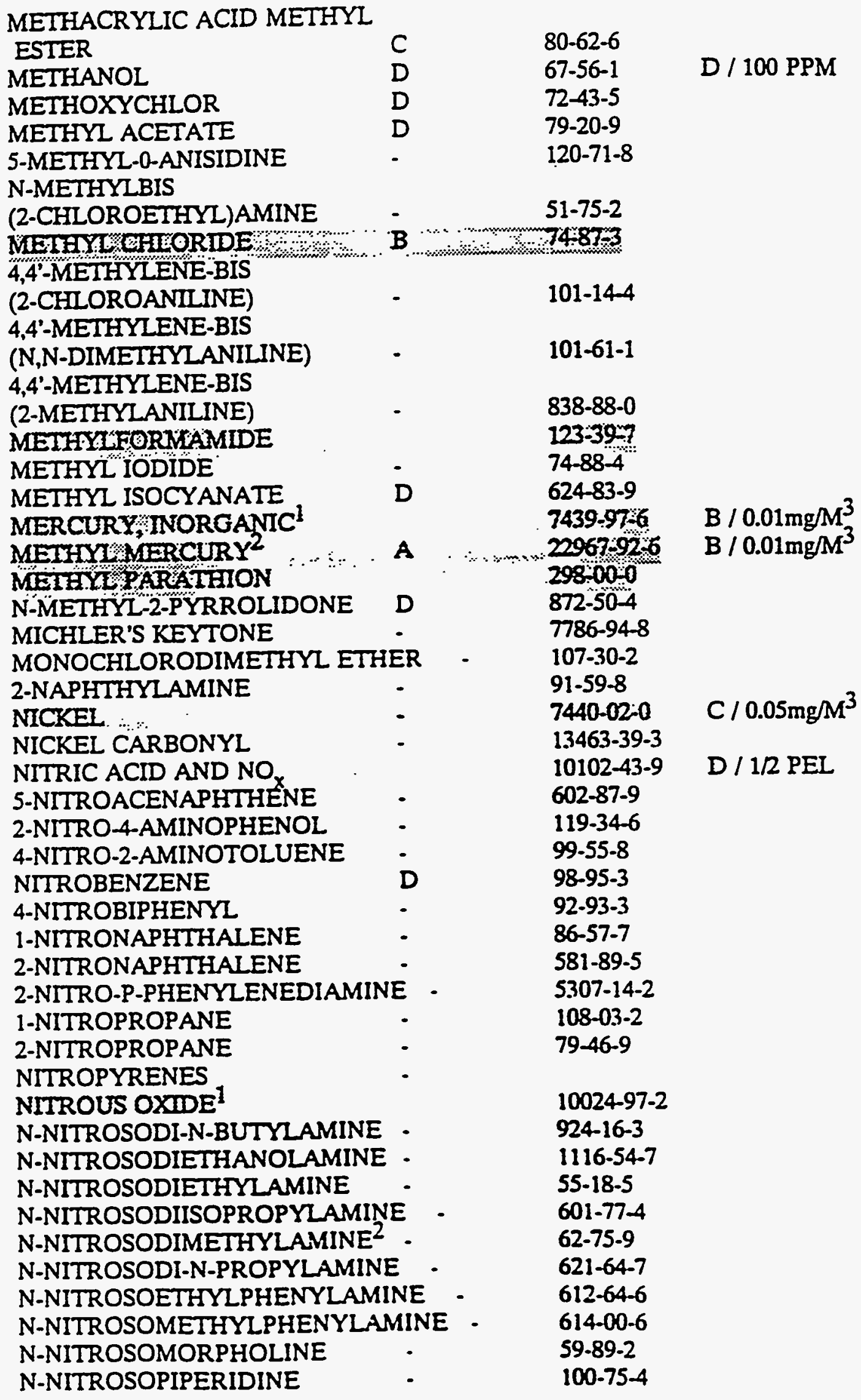









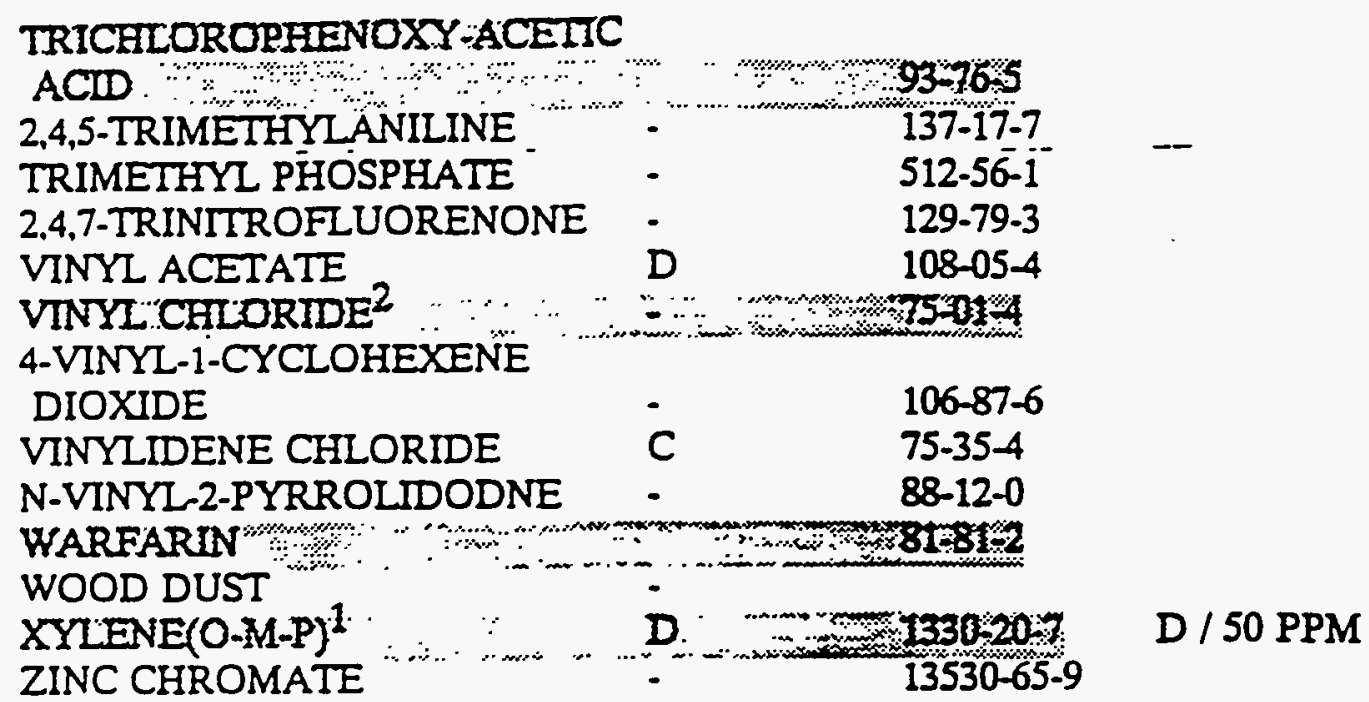

Group A: A risk of damage to the developing embryo or fetus has been unequivocally demonstrated. Exposure of pregnant women can lead to damage to the developing organism even when MAK and BAT values are adhered to.

Group B: according to currestly available information, a resk of damage to the developing embryo or fetus must be considered to be probable. Danage to the developing organism cannot be excluded when pregnant women are exposed even when MAK and $B A T$ values are adhered to.

Group C: There is no reason to fear a risk of damage to the developing embryo or fetus when MAK or BAT values are adhered to.

Group D: Classification in one of the groups A-C is not yet possible because although the dats available may indicate a trend they are not sufficient for a final evaluation. For each of these changes it is indicated. either in the individual evaluation report or in the collective repor "MAK Values and Pregnancy" of the series of publications"TToxikologisch-arbeitsmedizinische Begrundung von MAK-Werten", whether the currently available data speak for a classification in C or B and which further studies are considered to be necessary to achieve definitive classificationof the substance.

Group $\because$ Carcinogenic working materials without a MAK value.

Items specified by Dr. M. Paul, All? Conference, 5:93.

"1. Items previously listed in ESH-9.

.2n UC Corporate Potential Teratogen Listing, 5-20-81. 
. 
APPENDIX B

HUMAN AND SUSPECT HUMAN CARCINOGENS - OSHA AND ACGIH 
. 


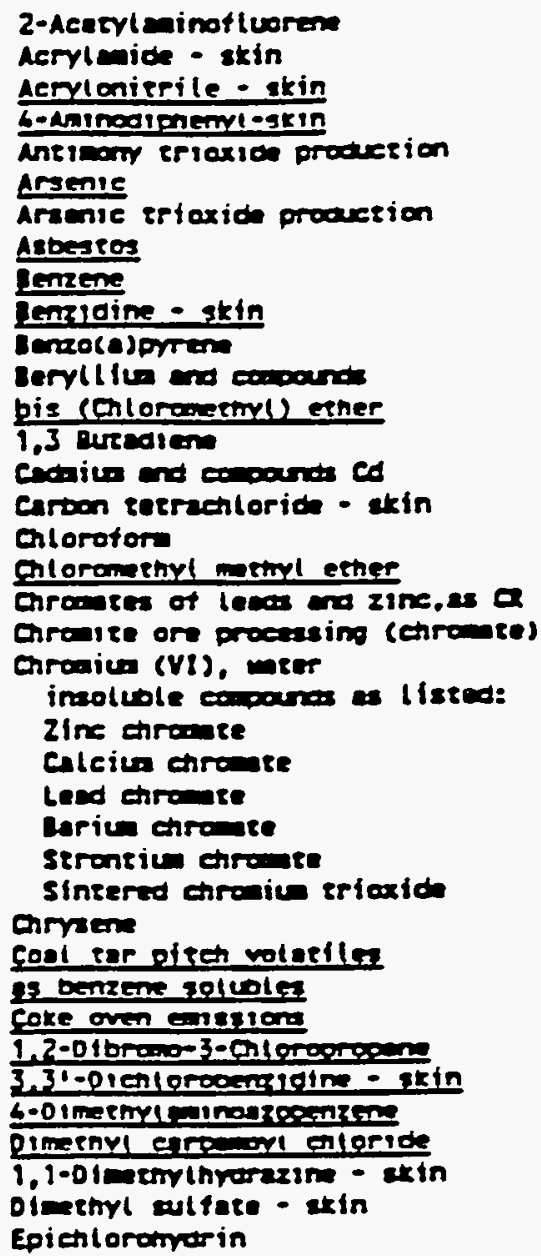

Eetrit acritate

Eand bre ids

Eantem dibroids - stin

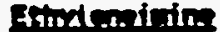

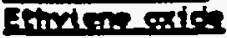

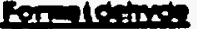

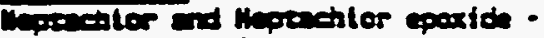
comenterctereadlate

cochlerexteren

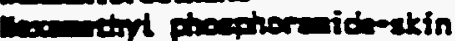

nycoin - atsin

6,61 nuturientis C .

chlorenilime etin (moce)

nutriter enterida

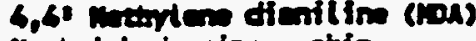

motid bydrexin - stin

netert ledids - ckin

micteit and. in oluble and colvtele co pards

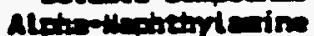

certe-intind ains

Silfredioticast

2-ilteroprep

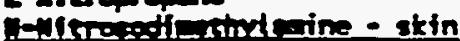

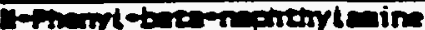

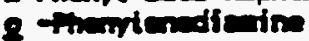

Prutbdroin - ekin

Prop in esters - atin

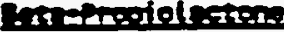

mopyentiste - Inin

rTaltin - un

Eralutinn - thin

-roluidin - aln

Trictureterin

vint broteds

Yined shlonts.

Vint Gyetarions diexide etin

ntidine (rixed isomese . etin 

ORNL/TM-12688

\section{INTERNAL DISTRIBUTION}

1-2. Central Research Library

3. Document Reference Section

4-5. Laboratory Records Department

6. Laboratory Records, ORNL RC

7. ORNL Patent Section

8-10. M\&C Records Office

9. J. K. Bain

10. R. L. Beatty

11. E. E. Bloom

13. R. A. Bradley

14. R. H. Cooper, Jr.

15. D. F. Craig

16. H. W. Hayden

17. L. L. Horton
18. C. A. Maples

19. M. C. Matthews

20. W. H. Miller

21. R. R. Judkins

22. R. B. Ogle

23. A. E. Pasto

24. V. J. Tennery

25. P. L. Rittenhouse

26. D. J. Walmsley

27. J. R. Weir, Jr.

28. H. W. Foglesong (Consultant)

29. E. L. Menger (Consultant)

30. J. G. Simon (Consultant)

31. K. E. Spear (Consultant)

EXTERNAL DISTRIBUTION

32. DOE, OAK RIDGE OPERATIONS OFFICE, P.O. Box 2001, Oak Ridge, TN 37831

Assistant Manager for Energy Research and Development

33-34. DOE, OFFICE OF SCIENTIFIC AND TECHNICAL INFORMATION, P.O. Box 62, Oak Ridge, TN 37831

For distribution as shown in DOE/OSTI-4500 